\title{
NATO reagavimo pajègų ir ES greitojo reagavimo pajėgų veiklos perspektyvos
}

Pasibaigus Šaltajam karui, reaguodamos ị pokyčius tarptautinejje aplinkoje, siekdamos efektyviai atsakyti ị naujus saugumo aplinkos iššūkius ir užsitikrinti savo raison d'etre keitesi ir saugumo institucijos. NATO buvo pradètos atitinkamos karinių vadovavimo struktūrų bei saugumo užtikrinimo instrumentų reformos. Pradètos kurti mobilios ir lankstesnès karinès pajègos, kurias galima būtu panaudoti regioniniuose konfliktuose. ES taip pat išplète funkcijas ị savo struktūras ịtraukdama karinị matmenị bei pradėdama kurti Europos greito reagavimo pajègas (EGRP).

Viena svarbiausių saugumo organizaciju misijų tapo taikos palaikymas. Tačiau taikos palaikymo instrumentai nebuvo pakankami kovojant su kitomis šiuolaikinėmis grèsmèmis, po $2001 \mathrm{~m}$. rugsejjo $11 \mathrm{~d}$. ypač aktualiais tapusiais masinio naikinimo ginklu plètra ir terorizmu. Afganistano karinè kampanija įrodè, kad nei ES, nei NATO nèra tinkamos operacijoms, kurios reikalauja operatyvumo ir lankstumo. Reaguodamas i tai JAV gynybos sekretorius Donald Rumsfeld pasiūle NATO Reagavimo pajëgų (NRP) projektą, numatantị NATO struktūrose sukurti mobilias greito reagavimo pajègas. NATO iqijo dar vieną misija užtikrinti tarptautinių krizių prevenciją ir krizių valdymą, įskaitant ir kovą su asimetrinemis grèsmèmis.

Naujai kuriamos struktūros, besikeičianti tarptautinė aplinka iškelia daug klausimu dèl būsimos Europos ir pasaulio saugumo institucijų „,architektūros“ formos, efektyvumo ir poveikio tarptautiniam saugumui. Šio straipsnio tikslas - pateikti nauju NATO ir ES karinių instrumentų veiklos perspektyvų analizę, išsiaiškinti, kokią rolę NRP ir EGRP atliks esamoje saugumo struktūroje, koks bus jų tarpusavio ryšys ir kaip visa tai veiks tarptautinį saugumą.

Pirmoje straipsnio dalyje analizuojamos NRP būsimos veiklos perspektyvos, galimos problemos, šiu pajègu įtaka NATO efektyvumui, transatlantiniam ryšiui ir tarptautiniam saugumui. Antra dalis skirta EGRP perspektyvu ir problemų analizei. Trečiojoje dalyje siekiama ịvertinti šių pajëgų bendros veiklos galimybes, svarbiausias problemas, ju ittaką pajègų veiklos efektyvumui ir pasekmes tarptautiniam saugumui. Paskutinejje dalyje trumpai apžvelgiamos Lietuvos dalyvavimo NRP ir EGRP operacijose perspektyvos.

Šaltojo karo pabaiga buvo tinkamas metas kitaip pažvelgti į tarptautiniuose santykiuose vyravusias sampratas, iš naujo įvertinti santykius tarp valstybių bei tarp valstybių ir nevalstybinių veikẻjų, peržvelgti iki tol vyravusias bendradarbiavimo struktūras akcentuojant visai kitas bendradarbiavimo funkcijas. Pagaliau Šaltojo karo metais egzistavusi priešprieša tarp blokų nebetrukdè valstybėms bendradarbiauti spendžiant globalaus pobūdžio problemas.

"Margarita Šešelgytė - Lietuvos karo akademijos Politikos mokslų katedros lektorè ir Vilniaus universiteto Tarptautinių santykių ir politikos mokslų instituto doktorantė. Adresas: Šilo 5a, 10322 Vilnius, tel. 8-5-2103569, e-paštas: margo_ses@yahoo.com 
Šaltojo karo pabaiga ir dvipolès pasaulio tvarkos žlugimas turëjo ir neigiamų pasekmių. Paaštrèjo iki tol dviejų blokų atgrasymo politikos ribojamos problemos, siejamos su technologine pažanga ir globalizaciniais procesais. Iškilo naujų saugumo problematikos klausimu, kuriems iki tol buvo teikiamas ribotas demesys, išaugo nekarinių grèsmių svarba. Modernių technologijų plètra, komunikacinių priemonių tobulèjimas, erdvès ir laiko svarbos sumažèjimas dar labiau suintensyvino neigiamų reiškinių plitimą ir destruktyvumą. Tarptautine migracija, tarptautinis nusikalstamumas, ekologinių problemų globalizacija, greitai besiplečiančios ekonominès krizės, socialiniai neramumai, etniniai konfliktai, terorizmas pasibaigus Šaltajam karui igavo naują prasmę. Visa tai lẻmè ir karinių grèsmių pobūdžio pakitimą. Karines grèsmes pradèta sieti ne tik su tarpvalstybiniais santykiais, bet ir su ịvairaus pobūdžio problemomis valstybių viduje. Dauguma karinių konfliktų po Šaltojo karo vyko ne tarp valstybių - tai tapo valstybių vidaus problema ir buvo sąlygoti nesutarimų tarp priešišku grupių valstybès viduje. Tradiciniai saugumo garantavimo instrumentai tapo neefektyvūs kovojant su naujomis grèsmėmis.

Efektyvių saugumo garantavimo instrumentų paieškas komplikavo ir neaiškus grèsmių apibrěžimas. Tradicinės grèsmès, vyravusios Šaltojo karo metais, buvo nesunkiai apibrěžiamos, joms nesunku buvo numatyti tinkamas prevencines ir kovos priemones. Šiandieninès grèsmès yra pakankamai miglotos, ne visos valstybės sutaria dèl šiu grèsmių apibrěžimo, be to, siekiant apibrèžti šias grèsmes, dažnai susiduriama su „vertybinio pobūdžio“ problemomis (šalies suvereniteto neliečiamumas, žmogaus teisių apsauga, agresoriaus ir aukos apibrěžimas). Su grèsmių pasikeitimu susijęs ir mūšio lauko apibrèžimo pokytis: mūšio lauko sąvoka taip pat tapo sunkiai apibrèžiama.

Saugumo problematikos pokyčiai bei jų destruktyvios pasekmės skatino valstybes bendradarbiauti ir ieškoti naujų prevencinių priemonių bei kovos būdų. Siekiant užtikrinti efektyvią tokios grèsmių įvairovès prevenciją bei kovą su jomis, reikalinga ịvairiapusè ir gerai išplètota institucinè struktūra, disponuojanti ịvairaus pobūdžio saugumo garantavimo instrumentais. Ilgalaikẻje saugumo užtikrinimo politikoje ypač reikšmingi tapo prevenciniai veiksmai ir civiliniai pajëgumai. Nors kolektyvinè gynyba išliko svarbi priemone kovojant su tradicinemis grèsmėmis, tačiau vis dažniau, ypač kai veiksmų būtina imtis nedelsiant, naudojami krizių valdymo instrumentai, jungiantys daug priemonių - nuo tiesioginès prievartos iki netiesioginių „,suvaržymų" tarptautinèse organizacijose. Karinejje srityje išaugo civilinių pajègumų reikšmé, taip pat atsirado poreikis turèti nedidelių specialios paskirties pajègų, besinaudojančių naujausiomis technologijomis bei moderniausiomis oro pajègomis, operatyviais žvalgybiniais pajègumais. Tai sąlygojo kovos priemonių, karinių pajègų ir ginkluotès pokyčių būtinybę.

Reaguodamos į kintančią saugumo aplinką, keisdamos savo tikslus, uždavinius, struktūras ir kurdamos naujus instrumentus, kinta ir saugumo institucinès struktūros. Pasibaigus Šaltajam karui, reaguojant į pokyčius tarptautinèje aplinkoje, keitèsi saugumo organizacijų misijos. Šaltojo karo metais NATO garantavo kolektyvinę gynybą ir atgrasymą. Šaltajam karui pasibaigus, organizacija, siekdama užsitikrinti savo raison d'etre ir efektyviai atsakyti į naujus saugumo aplinkos iššǔkius, ėmėsi naujos misijos - taikos palaikymo. Buvo pradètos atitinkamos NATO karinių vado- 
vavimo struktūrų bei priemonių reformos. Pradètos kurti mobilios ir lankstesnès karinès pajègos, kurias galima būtų panaudoti regioniniuose konfliktuose. ES taip pat nusprendè išplèsti savo funkcijas struktūrose - pradejjo kurti karinị matmenị. 1998 m. Kelno viršūnių taryboje ES perėmus VES funkcijas, numatyta kurti Europos greito reagavimo pajëgas (EGRP), kurių tikslas - vykdyti humanitarines operacijas, gelbèjimo darbus, taikos palaikymą ir krizių valdymą. EGRP 2003 m. gegužès mėn. paskelbtos veiksniomis ir šiuo metu jau vykdo misijas Makedonijoje ir Kongo Demokratineje respublikoje. Vis dèlto taikos palaikymo instrumentai nebuvo pakankami kovojant su kitomis šiuolaikinėmis grèsmėmis - po 2001 m. rugsẻjo 11 d. ypač aktualiais tapusiais masinio naikinimo ginklų plètra ir terorizmu. Afganistano kariné kampanija įrodè, kad nei ES, nei NATO nèra tinkamos operacijoms, kurios reikalauja operatyvumo ir lankstumo. Tapo akivaizdu, kad jei NATO neigis naujų instrumentų kovai su būsimais iššūkiais, dauguma karinių operacijų vyks laikinų koalicijų struktūrose ir tai turès neigiamą įtaką Aljanso svarbai. Pradèta ieškoti naujų organizacijos reabilitavimo būdų bei naujų kovos su šiomis grèsmėmis priemonių. Reaguodamas į tai JAV gynybos sekretorius Donald Rumsfeld pasiūlè NATO Reagavimo pajėgų (NRP) projektą, numatantį NATO struktūrose sukurti mobilias greito reagavimo pajëgas. NATO ịgijo dar vieną misiją - užtikrinti tarptautinių krizių prevenciją ir krizių valdymą, įskaitant ir kovą su asimetrinèmis grèsmėmis.

Tarptautinių saugumo organizacijų transformacija, prasidèjusi pasibaigus Šaltajam karui, tebevyksta. Nepaisant to, kad ši transformacija jau vyksta daugiau negu dešimt metų, jos pasekmés lieka neaiškios ir skatina nuolat vertinti galimų pokyčių įtaką organizacijų efektyvumui ir tarptautiniam saugumui. Šio straipsnio tikslas pateikti naujų NATO ir ES karinių instrumentų veiklos perspektyvų analizę, išsiaiškinti, kokią rolę NRP ir EGRP atliks esamoje saugumo struktūroje, koks bus jų tarpusavio ryšys ir kaip visa tai veiks tarptautinį saugumą.

Pirmoje straipsnio dalyje analizuojamos NRP būsimos veiklos perspektyvos, galimos problemos, šių pajëgų įtaka NATO efektyvumui, transatlantiniam ryšiui ir tarptautiniam saugumui. Antra dalis skirta EGRP perspektyvų ir problemų analizei. Trečiojoje dalyje siekiama ịvertinti šių pajègų bendros veiklos galimybes, svarbiausias problemas, jų itaką pajègų veiklos efektyvumui ir pasekmes tarptautiniam saugumui. Paskutinèje dalyje trumpai apžvelgiamos Lietuvos dalyvavimo NRP ir EGRP operacijose perspektyvos.

\section{NATO reagavimo pajėgos (NRP) - Aljanso atgaivinimo priemoné}

Pagrindinė mintis, nuskambẻjusi 1990 m. NATO Romos viršūnių susitikime, buvo tokia: Šaltasis karas pasibaigè, Europa ịžengè ị naują erą ir naujai Europai reikia naujos NATO. Prasidejo aštrios diskusijos dèl Aljanso ateities. Dalis diskutuojančiujjų mané, kad NATO dienos suskaičiuotos, kad, nebelikus pagrindinio motyvuojančio veiksnio - komunistinio bloko keliamos grèsmés, organizacija bus pasmerkta nunykti. Pasigirdo nuomonių, kad konfliktų era baigési ir pasaulis po truputị žengia ị liberalizmo, demokratijos ir taikos amžių. Pasauliniu bestseleriu tapusioje 
Francis Fukuyama knygoje „Istorijos pabaiga ir paskutinis žmogus“1 buvo piešiamas naujas taikaus pasaulio vaizdas, susilaukęs daugybės pasekejų įvairiose šalyse. Tačiau šią viziją sugriovè jau pirmaisiais metais po Šaltojo karo prasidejję ginkluoti konfliktai Jugoslavijoje bei buvusios SSSR teritorijoje.

Konfliktai Balkanuose, ko gero, ir buvo tas pagrindinis impulsas, suteikęs galimybę Šiaurès Atlanto Aljansui ịrodyti, jog, nors komunistinè grèsmė dingo, jis yra reikalingas. Naujų, iš Sovietų Sajungos globos išsilaisvinusių šalių siekiai tapti NATO narėmis bei Aljanso sėkmè İlankos kare dar labiau sutvirtino organizacijos raison d'etre.

Nors kolektyvinė narių gynyba išliko pagrindine NATO misija, jau pirmaisiais paskutiniojo dešimtmečio metais NATO èmési naujos misijos - taikos palaikymo. Dèl padidẻjusios krizių prevencijos ir valdymo misijų paklausos, saugumo aplinkoje susiformavusioje po Šaltojo karo, $1992 \mathrm{~m}$. Šiaurès Atlanto Taryba (NAC) susitikime Osle ịsipareigojo remti taikdarystés operacijas ${ }^{2}$. JAV inicijavo diskusijas dèl NATO reformos. O 1990 m. priimtos dvi deklaracijos - ES -JAV ir ES - Kanada - skelbè būtinybę transformuoti NATO iš karinès ị daugiau politinio pobūdžio organizaciją, apimančią kolektyvinio saugumo palaikymo užduotis. Deklaracijose taip pat buvo nuspręsta pertvarkyti NATO karines pajëgas, igalinant jas veikti Petersbergo užduočių rèmuose ir pritaikant kovai su naujomis grèsmėmis, kurioms valdyti reikalingas lankstumas ir mobilumas.

NATO ir Aljanso partnerių pajėgos dalyvavo taikos palaikymo misijose Bosnijoje ir Hercegovinoje, Kosove, Makedonijoje. Vis dèlto vykdyti naujają misiją NATO sekèsi sunkiai. Paaiškejjo, kad šiuose naujo pobūdžio konfliktuose NATO pajègos nèra efektyvios. Serbai ir čigonai bėgo iš Kosovo ne todèl, kad jie laike NATO savo priešais, bet todèl, kad nepasitikèjo NATO, kaip institucija, galinčia įvykdyti policininko funkcijas. Su panašaus pobūdžio problemomis NATO susidūrẻ ir kituose konfliktuose (Bosnijoje - Hercegovinoje bei Kroatijoje). Buvęs JAV Gynybos sekretorius William Cohen, vertindamas Aljanso galimybes vykdyti naująą organizacijos misiją, atkreipé dėmesi, kad taikos palaikymo misijų igyvendinimas reikalauja visiškai kitokio pasirengimo bei kitokiu pajėgų. Karinè jëga tokiose misijose ne visada yra optimaliausias sprendimo variantas ${ }^{3}$. Kita vertus, NATO operacijoms už Aljanso ribų buvo reikalingas Jungtinių tautų (JT) mandatas. JT mandato gavimo procedūra sulètindavo operacijų eigą, o pats mandatas dažnai ịsprausdavo NATO pajėgas ị tokius siaurus galimos veiklos rèmus, kad ne tik sumažindavo NATO operacijų efektyvumą, bet keldavo pavojų karių saugumui. Ir nors NATO buvo kritikuojama dẻl nesugebéjimo sureguliuoti regioninius konfliktus, verta pripažinti, kad tai buvo vienintelè organizacija, sugebèjusi pasiųsti karines pajègas į konfliktų regionus.

Sunku nustatyti, kas labiausiai sąlygojo NATO atgimimą: ar konfliktai Balkanuose, ar Ịlankos karas, ar didelis Vidurio ir Rytų Europos šalių noras įstoti ị šią organizaciją, ar institucinis inertiškumas ${ }^{4}$, ar tai, kad neatsirado né vienos organiza-

\footnotetext{
${ }^{1}$ Fukuyama F., The end of history and the last man, New York, Macmillan, 1989.

${ }^{2}$ Ministerial Meeting of the North Atlantic Council Final Communique, Oslo, 4 June 1992, http:/ /www.nato.int/docu/comm./htm.

3 „Peacekeeping Not NATO's Job says Cohen“, Press Advissory: Basic Publications, 16 July 1999, http://www.basicint.org/pr_natopk.html.

${ }^{4}$ Cornish P., „Partnership in Crisis: the US, Europe and the Fall and Rise of NATO“ in Chatam

House Papers, London, Royal Institute of International Affaires, 1997, 4.
} 
cijos, galinčios pakeisti NATO. Tikriausiai visų šių veiksnių kompleksas užtikrino, kad NATO išliko reikšminga saugumo organizacijoje. Siekiant sustiprinti Aljanso gynybinį pajègumą, buvo pradètos NATO karinių vadovavimo struktūrų bei priemonių reformos. Pradètos kurti mobilios ir lankstesnès karinès pajègos, kurias galima būtų panaudoti regioniniuose konfliktuose. Taikos palaikymui skirtas pajègas buvo planuojama įsteigti Europos saugumo ir gynybos identiteto (ang. European Security and Defense identity (ESDI)) rèmuose mažai ginkluotiems europiečių daliniams suteikiant civilinès administracijos, policijos, konfliktų sprendimo, rinkimų organizavimo ir stebẻjimo bei žiniasklaidos monitoringo funkcijas. ${ }^{5}$ Vašingtono viršūnių susitikime buvo pristatyta ir Gynybinių pajègumų iniciatyva (DCI), kurios tikslas patobulinti NATO pajëgumus, siekiant pritaikyti juos krizių valdymui. Numatytos ịvairios reformų kryptys: mobilumo, logistikos, ilgalaikiškumo bei efektyvaus veikimo, vadovavimo, kontrolès, informacinių sistemų srityse.

NATO susidorojus su krize ir suradus naują vaidmenį šiuolaikiniame pasaulyje, daugelis NATO tyrèjų prakalbo apie naują Aljanso erą. Tačiau optimizmas vyravo neilgai. Pirmaisiais naujojo tūkstantmečio metais vèl svarstome NATO išlikimą. Ir nors po $2001 \mathrm{~m}$. rugsẻjo 11-osios teroristinių išpuolių JAV parodyta NATO vienybẻ demonstravo Aljanso tvirtumą ir aktyvumą, Afganistano karinè kampanija įrodé, kad NATO nesugeba atlikti operatyvumo ir lankstumo reikalaujančiu operacijų. Be to, amerikiečiai nèra linkę remtis Aljansu vykdydami savo gynybą. Amerikiečių ir britų karinè kampanija Irake tik dar labiau susilpnino NATO reikšmę.

Ko gero, pagrindiné šiandieninių Aljanso problemų priežastis yra NATO gyvavimo ramsčio - transatlantinio ryšio - silpnejjimas. Šios problemos atsiradimą lėmé daugelis faktorių: JAV strateginių prioritetų pasikeitimas po Šaltojo karo; Europos ekonominès ir politinès reikšmès augimas, tačiau drauge milžiniškas atsilikimas nuo JAV karinių pajėgumų srityje; JAV suinteresuotumo NATO atžvilgiu sumažėimas ir vienašališkumas tarptautinèje politikoje; europiečių bandymai kurti naujas pajëgas mažo intensyvumo taikos palaikymo operacijoms vykdyti ir dar daug kitu veiksnių. Verta atkreipti dėmesį ir ị abejotinas NATO galimybes kovoti su, matyt, svarbiausiomis XXI amžiaus pradžios grésmėmis - masinio naikinimo ginklų nekontroliuojama plètra bei terorizmu.

Europiečiai, susirūpinę Aljanso reikšmès mažèjimu, kaltino amerikiečius vienašališkumu ir visas NATO problemas buvo linkę sieti su amerikiečių nenoru remtis daugiašalėmis institucijomis. Amerikiečiai savo ruožtu buvo linkę daugiau akcentuoti šio nenoro priežastis ir kalbẻjo apie netobulą Aljanso struktūrą, sudètingą ir ilgą sprendimų prièmimą, JT suvaržymus, europiečių karinị atsilikimą.

Nei europiečiai, nei amerikiečiai kol kas nèra suinteresuoti Aljanso išnykimu, tačiau NATO, toks, koks yra šiandien, nesugeba adekvačiai reaguoti į šiuolaikinius saugumo iššǔkius ir nepatenkina nei amerikiečių, nei europiečių lūkesčių. Šiandieninis NATO atlieka veikiau politinio forumo, o ne karinio aljanso funkcijas. Žinoma, netgi kaip politinis forumas Šiaurès Atlanto Aljansas yra naudingas skatinant bendradarbiavimą ir demokratijos plètrą, tačiau ar tokị Aljansą nori matyti jo nariai XXI amžiuje?

5 „ESDI: Right Debate, Wrong Conclusions“ Press Advisory: Basic Publications 8 September 2000, http://www.baisicint.org.ciuunits.htm. 
Akivaizdu, kad jei NATO neigis naujų instrumentų kovai su naujais iššūkiais, dauguma karinių operacijų vyks laikinų koalicijų struktūrose. Tačiau laikinos koalicijos nėra pats geriausias sprendimas. Nepaisant galimos laikinų koalicijų teikiamos naudos, bendradarbiavimas šiose koalicijose dažniausiai būna trumpalaikis, nukreiptas prieš konkrečią grèsmę ir vyksta tik tol, kol tenkina dalyvaujančių šalių lūkesčius. Jis nesuteikia ilgalaikių saugumo garantijų bei neatlieka visų saugumo politikos funkcijų. Nuolatinès saugumo institucijos ne tik suteikia galimybes kartu kovoti prieš grèsmes, bet turi ir drausminantị poveikį, kuris padeda išspręsti svarbių tarptautinių santykių „netikrumo problemą“. Bendromis taisyklèmis, institucijomis, elgsenos modeliais ilgainiui stiprindamos bendrą identitetą, ilgalaikès institucijos skatina glaudesnį bendradarbiavimą, daugiašališkumą, taip pat pačios tampa svarbiu pasaulio saugumo veiksniu. Laikinos koalicijos, vykdydamos karines operacijas, daug dažniau susiduria su legitimumo problema. Tai, beje, irodè ir amerikiečių bei britų bendros koalicijos, nukreiptos prieš Irako režimą, kritika.

Taigi tinkamos nuolatinès bendradarbiavimo struktūros turbūt būtų geresnis kovos su tarptautiniais iššūkiais būdas, nei rẻmimasis išimtinai laikinomis koalicijomis. Tikètina, kad suvokdami tai Aljanso nariai nusprendè suteikti organizacijai dar vieną galimybę irodyti savo reikalingumą. Kadangi pagrindinès grèsmès šiandieniam saugumui - terorizmas ir nekontroliuojama masinio naikinimo ginklų plètra, NATO turi būti pasirengusi su jomis kovoti. Prasidejjus XXI amžiui NATO ịgyja dar vieną misiją - užtikrinti tarptautinių krizių prevenciją ir krizių valdymą, taip pat ir kovą su asimetrinèmis grèsmèmis. ${ }^{6}$ Ar NATO sugebès atsakyti ị š ši iššūkị??

Spalio 6 d. NATO Parlamentinés Asamblejos Deklaracijoje dèl Aljanso transformacijos buvo skelbiama, kad NATO privalo ịtvirtinti gynybą prieš terorizmo ir masinio naikinimo ginklų grésmes, ypatingą dèmesị teikiant kovai su biologinių, cheminių ir radiologinių ginklų plitimu? ${ }^{7}$ Neformalaus NATO gynybos ministrų susitikimo, vykusio $2002 \mathrm{~m}$. rugsejo $24 \mathrm{~d}$. Varšuvoje, atidarymo proga pasakytoje kalboje JAV Gynybos sekretorius Donald Rumsfeld pabrěžè, kad „kol NATO neturès mobilių ir greitų pajëgų, kurias galima būtų dislokuoti per kelias dienas ar savaites, o ne per kelis mėnesius ar net metus, ši organizacija galès nedaug ką pasiūlyti XXI amžiuje“"8.

Siekdamas sutvirtinti savo žodžius praktiniais įrodymais valstybėms narèms pasiūle NATO Reagavimo pajègų (ang. NATO Reaction Force) NRP projektą, numatantį NATO struktürose sukurti mobilias greito reagavimo pajègas (apie 20000 karių) su visais sausumos, oro, jūrų pajëgų ir vadovavimo elementais, kurias galima būtų dislokuoti per 7-30 dienų. Šios pajègos neturès geografinių apribojimų ir iš esmès bus skirtos vykdyti operacijas už NATO ribų. NRP bus sudaromos iš NATO narių karinių pajègų užtikrinant aukštą parengties lygị, tačiau parengtyje NRP nebus laikomos nuolat, o tam tikra pajègų dalis bus vienoje arba kitoje rotacijos fazejje - mokymuose, misijoje arba nuolatinejje parengtyje. Kol pajegos bus nuolatinès parengties fazejje joms

\footnotetext{
${ }^{6}$ Lordo George Robertson kalba, pasakyta Charles Universitete Prahoje 2002 m. kovo 21 d., http:/ /www.kam.lt /index.php?ItemId = 11647

${ }^{7}$ Simpson F., Lindborg Ch., „The Results of the Prague Simmuit and Challenges Ahead“ http:// www.basicint.org/update/041202_PF.htm.

${ }^{8}$ BBC News World Edition, http://news.bbc.co.uk/2/hi/europe/default.stm, 25092002.
} 
vadovaus nacionalinė karinè vadovybė, o krizės atveju - Sajungininkų pajėgų Atlante vyriausiasis vadas (SACEUR). Pagrindinès NRP kūrimo planuose numatomos operacijos: 1) jègos demonstravimas; 2) savarankiškas plataus operacijų vykdymas; 3 ) išskleidimo operacijų vykdymas pagrindinių pajègų išskleidimui užtikrinti. Taip pat planuojama sukurti naują cheminị, biologinị, radiologinị ir branduolinị batalioną, kuris bus įtrauktas ị NRP.

2002 m. lapkričio mèn. Prahos viršūnių susitikime dėmesys buvo skiriamas dviem pagrindiniams klausimams: NATO misijai XXI amžiuje ir tinkamiausių struktūrų naujoms užduotims igyvendinti paieškoms. Prahoje taip pat buvo svarstomos NRP, dèl kurių sutarta, kad jos turi pradèti veikti kuo greičiau, t. y. ne vèliau nei $2004 \mathrm{~m}$. spalio mèn. o pilną pajẻgumą pasiekti ne vẻliau kaip $2006 \mathrm{~m}$. tą patị mènesį.

NRP projektas buvo vertinamas labai ịvairiai. Kai kurie apžvalgininkai tvirtino, kad šis JAV pasiūlymas tebuvo siekis sumažinti plètros politikos reikšmę ir nuraminti rusus. Kiti teigè, kad tai - būdas suteikti NATO sąungininkams paskutinę galimybę pagerinti savo karinius pajėgumus. Dar kiti manè, jog šiuo projektu buvo siekta sumažinti sajungininkų nuogąstavimus dèl augančio JAV izoliacionizmo ir suteikti naują pagrindą bendradarbiauti JAV, NATO ir ES.

JAV pasiūlymui kurti NRP be prieštaravimų iš karto pritare visi sajungininkai ${ }^{9}$. Tačiau kyla pagrịstas klausimas: ar iš tiesų NRP yra panacėja nuo visų NATO kamuojančių ligų? O gal tai tik JAV būdas įtvirtinti savo dominavimą? Gal tai tik geriausia iš galimų blogybių, kurią europiečiai yra priversti rinktis?

Pradejjus veikti NRP, NATO iš regioninès gynybinès organizacijos būtų transformuojamas į , ,agresyvų“ aljansą, globaliai naudojantį savo karines pajègas. Ši transformacija tikrai nèra visiškai suderinama su europietiškuoju identitetu, kuris remiasi „regioninio - civilinio“veikejo role. Tai, kad NRP yra sukurtos preventyviems smūgiams prieš „išdykusias“ (angl. rogue)

valstybes ir, amerikiečių supratimu, neturètų priklausyti nuo JT Saugumo tarybos mandato, kertasi dar su vienu europiečių taip vertinamu tarptautinės teisès principu - valstybės suvereniteto viršenybe. Ronja Kempin savo straipsnyje apie NRP cituoja Prancūzijos gynybos ministrę, kuri, kalbėdama apie iniciatyvą, teige, kad NATO geografinio apibrèžtumo panaikinimas yra pavojingas, kadangi „sukuria galimybes imtis veiksmų bet kokiomis sąlygomis"10. Gynybos ministre užduoda pagrịstą klausimą „Kas spręs?“. Taigi ar NRP nėra būdas įteisinti JAV dominavimą?

Vis dèlto NRP projektas naudingas ir europiečiams. Naujoji G. W. Bush strategija vos užsiminé apie Europą ir NATO, europiečiai ėmé nuogąstauti, kad JAV nusisuks nuo NATO ir Europos. Neturintys pakankamų karinių pajègumų europiečiai yra ypač suinteresuoti JAV galvojimu apie Europą, o svarbiausias šį galvojimą užtikrinantis veiksnys - NATO. Kadangi NRP kūrimo pasiūlymas yra vertinamas kaip paskutiné NATO galimybe įrodyti savo reikalingumą, tai neabejotinai svarbu ir naudinga europiečiams. Kita vertus, NRP - tai pigus būdas reabilituoti europiečiu karinius pajëgumus, kai mažiausiomis sąnaudomis yra gaunama maksimali vertè.

\footnotetext{
${ }^{9}$ Financial Times, 24 September 2002.

${ }^{10}$ Kempin R., ,"The new NATO Responce Force: Challenges for and Reactions from Europe“, http:/ /www.copri.dk/publications/Wp/WP\%202002/29-2002.doc.
} 
NRP kuriamos specialių Aljanso sajungininkų pajëgumų pagrindu ir bus sudarytos iš NATO narių pajègų, kurios mokysis kartu ir rotuosis kas šešis mėnesius. NATO Generalinis Sekretorius George Robertson jau prieš Prahą agitavo NATO nares ieškoti galimo indèlio į NRP. Šie įnašai turètų sumažinti pajègumų skirtumą, egzistuojanti tarp JAV ir Europos sajungininku (2002 m. JAV gynybai išleido 355 mlrd. USD, o NATO nariai europiečiai - tik $260 \mathrm{mlrd} .{ }^{11}$ ). İ NRP projektą buvo įtraukta „specialių pajëgumų“ (ang. niche capabilities) sąvoka, užtikrinsianti geresnị pasirengimą naujoms misijoms nedidinant gynybos išlaidų. Europiečiams svarbi dar viena detalè: šios pajėgos turès bendrus žvalgybinius, planavimo ir vadovavimo bei kontrolès pajëgumus - būtent tai, ko Europos karinès pajègos neturi. Pagaliau dalyvavimas NRP vykdomose misijose suteiks galimybę europiečiams bent jau dalyvauti priimant sprendimus: tai būtų neįmanoma, jei JAV, apeidama NATO struktūras, remtųsi laikinomis koalicijomis. Taigi galima teigti, kad šis NRP europiečiams vis dèlto yra naudingas. O kokią naudą turès amerikiečiai?

G. W. Bush, West Pointo Karo akademijoje kalbėdamas apie naujają JAV Nacionalinio saugumo strategiją akcentavo, kad JAV „saugumui užtikrinti reikalinga kariuomenè, kuri yra pasiruošusi akimirksniu suduoti smūgị ị bet kurị, net tamsiausią pasaulio kampą"12 . JAV $2001 \mathrm{~m}$. Nacionalinio saugumo strategijoje pabrež̌iama, kad nors kolektyvinè transatlantinio demokratiškų šalių Aljanso gynyba išlieka pagrindine NATO misija, NATO privalo sukurti naujas struktūras ir pajëgumus igyvendinti šia misiją naujomis aplinkybėmis ${ }^{13}$. Šios citatos ir tai, kad NRP iš esmés yra amerikiečiu pasiūlymas, ko gero, jau yra svarbus įrodymas, jog šis projektas yra naudingas JAV. Vis dèlto verta atkreipti dėmesi i $i$ tai, kad JAV ir taip turi reikalingus pajėgumus tokioms misijoms vykdyti. Tai įrodė karinės operacijos Afganistane ir Irake. Kodėl JAV reikëjo kurti tokias pajėgas NATO struktūrose? Pirma, ko gero, dèl to, kad, nežiūrint Europos reikšmės sumažějimo JAV strateginiame mąstyme, Europa išlieka svarbi JAV, o NATO suteikia galimybę išlikti Europoje. Antra, pradẻjus veikti NRP, JAV laimès - turès nors ir nedidelę karinę paramą, todẻl sumažès JAV dalyvavimo karinèse operacijose kaštai. Vis dèlto bene svarbiausias JAV laimëjimas - veiksmų legitimumas, kurio ji nesugebèjo užsitikrinti Irake. Taigi panašu, kad šiuo projektu yra suinteresuoti tiek amerikiečiai, tiek europiečiai, ir visi stengsis ši projektą sèkmingai įvykdyti.

Vertinant šio projekto perspektyvas, verta atkreipti demesị i keletą problemišskų sričių. Pirma, nepaisant vieningo pritarimo NRP Prahoje, tarp NATO narių egzistuoja esminių skirtumų, galinčių neigiamai veikti NRP perspektyvas. Nors pajègos, kurių viena pagrindinių užduočiu yra kova prieš terorizmą, turètų vadovautis tuo pačiu terorizmo apibrěžimu bei kovos samprata. JAV ir Europos vizijos dẻl kovos su svarbiausiomis globaliomis problemomis ir grèsmèmis labai skiriasi. Dažnai amerikiečiai ir europiečiai netgi skirtingai apibrěžia šias problemas ir grèsmes ${ }^{14}$. Pavyz-

\footnotetext{
${ }^{11}$ Powell S. M., Rosenberg E., „NATO plans multinational rapid deployement force 20,000 troops ready to hit trouble spots within days", http://sfgate.com/cgi-bin/article.cgi?f=/s/a/2002/11/17/ MN111299.DTL.

${ }^{12}$ Smith D., „Preemptive Peace“, http://www.fcnl.org/issues/mil/sup/peacekeeping_force716-03.htm.

${ }^{13}$ The National Security Strategy of the United States of America, September, 2002.

${ }^{14}$ Van Ham P., Kugler R. L., „Western Unity and the Transatlantic Security Challenge“, Marshall

Center Papers, http://www.marshallcenter.org/CISS/English/Mcpapers, 20.
} 
džiui, amerikiečiai Saddam Hussein režimą vertino kaip keliantį terorizmo grèsmę, panašią i tą, su kuria amerikiečiai susidūrè $2001 \mathrm{~m}$. rugsẻjo $11 \mathrm{~d}$. Dauguma europiečiu nemanè, kad šis režimas kelia terorizmo pavojų, kita vertus, jie nesutiko su amerikiečių pasirinktomis kovos su šia grèsme priemonėmis. Amerikietiškas savo esme NRP projektas kai kurioms NATO šalims (pavyzdžiui, Prancūzijai ir Vokietijai) neišvengiamai sukurs dilemą, kylančią dèl kitokio šių šalių požiūrio ị prevencinius karinius veiksmus ir terorizmo apibrěžimą. Taip pat egzistuoja ženklus skirtumas apibrèžiant vadinamas piktavales valstybes ir jų problemas. JAV jas suvokia kaip neatitinkančias tarptautinès visuomenès keliamu reikalavimu ir siekia izoliuoti. Europiečiai mano priešingai: šias šalis reikia integruoti į tarptautinę visuomenę ir taip bandyti spręsti jų problemas. Kol egzistuoja šie skirtumai, tikètina, kad įtampa tarp Europos ir JAV augs. Jau dabar vyksta aštrios diskusijos dẻl sąlygų, kuriomis NRP turi būti naudojamos.

Antra problemų grupè yra daugiau sietina su kariniais pajėgumais. NATO pajėgų kūrejjai baiminasi, kad politiniai lyderiai NRP vertins kaip vaistą nuo visų ligų ir reikalaus iš šiu pajègų daugiau, negu jos bus pajegios ịvykdyti. NRP gali būti verčiamos įsitraukti ị labai ịvairaus pobūdžio misijas. Neaiškumų kyla ir dèl NRP struktūros: ar tai bus vienas darinys, ar keli. Nèra apibréžiama ir tai, ar oro, sausumos ir jūros pajëgos sudarys vieną vienetą, ar kelis atskirus.

NRP efektyvumas neišvengiamai priklausys ir nuo sprendimų priėmimo proceso. Sprendimą dèl NRP dislokavimo, esant galimybei, turètų priimti Šiaurès Atlanto taryba (ŠAT), kitais atvejais - NATO Gynybos planavimo komitetas, kuriame nedalyvauja prancūzai. Prancūzai griežtai pasisako prieš tokị planą ir tvirtina, kad sprendimas turètų būti priimamas ŠAT. Tačiau visais atvejais sprendimo teisès suteikimas ŠAT neišvengiamai sąlygotų NRP neefektyvumą, nes sulètės NRP dislokavimo laikas. Kmdr Dick Lacey netgi siūlo siekiant efektyvių NRP suteikti SACEUR teisę planuoti misijas dar iki tol, kol yra pasiekiamas politinis susitarimas ${ }^{15}$. Dar komplikuotesnis gali būti sprendimų prièmimas sostinèse. Siekiant dislokuoti NRP pajëgas, kiekviena valstybė nare turės patvirtinti savo sprendimą pagal šalies įstatymų numatytas procedūras. Kyla klausimas ar lètos pajègų siuntimo įteisinimo procedūros šalies parlamentuose netaps NRP paralyžiuojančiu veiksniu.

2003 m. spalio 8-9 d. Kolorado Springse (Colorado Springs) NATO gynybos ministrai apžvelgè NRP projekto iggyvendinimą. Jie kartu su kitais šalių narių kariuomenių, politiniais ir NATO aukštais pareigūnais pasitelkdami „simuliacinį žaidimą" pabandè ịvertinti, kaip NRP galètų kovoti su asimetrinėmis grèsmèmis šiandieninemis sąlygomis. Pagrindine mintis, nuskambejjusi iš tuometinio NATO generalinio sekretoriaus George Robertson lūpų po šio bandymo, buvo ta, kad Aljansui reikia realių karių, o ne „popierinių kariuomeniu““. Jo manymu, seminaras Kolorado Springse leido politikams ir kariškiams surasti daug bendrų sprendimų įvairiais su NRP susijusiais klausimais. Jie suvokè, kad NATO kovodama su krizėmis ateityje privalès pagreitinti sprendimų prièmimo procedūras valstybėse narėse, o šios problemos sprendimui pasitarnautų išankstinis planavimas. ${ }^{16}$

\footnotetext{
${ }^{15}$ 2-4 July, 2003 - visit to the UK by the Defence and Security Sub-committee on Transatlantic Defence and Security Co-operation, http://www.naa.be/default.asp?shortcut $=406$.

${ }_{16}$ Porth J.S., „Robertson says NATO transformation must be completed“ Washington File, 08 October 2003, http://usinfo.state.gov/usinfo/products/washfile.html.
} 
$2003 \mathrm{~m}$. spalio 15 d. NRP formaliai pradèjo veikti. Tačiau nepaisant europiečių ir amerikiečių suinteresuotumo šiuo projektu, išlieka daug svarbių klausimų, nuo kuriu sprendimo priklausys NRP perspektyvos. Ar formaliai pradejjusios veikti NRP bus sėkmingos praktikoje? Ar NATO sugebès vykdyti misijas už savo teritorijos ribų? Kokios tai bus misijos? Ar pavyks pagreitinti NATO sprendimų prièmimo procedūrą (ypač svarbu NATO plečiantis)? Kokie bus NATO santykiai su kitomis tarptautinėmis organizacijomis, ypač su ES? Ir pagaliau koks bus JAV požiūris i NATO? Ar JAV ị NATO žvelgs kaip ị instrumentų rinkinį, iš kurio galima susikonstruoti laikinas koalicijas, ar vertins kaip naudingą organizaciją su visais nuolatinių bendradarbiavimo struktūrų teikiamais privalumais?

\section{ES Greito reagavimo pajègos (EGRP) ir jų vystymo perspektyvos}

1991 m. Maastrichto viršūnių tarybos susitikime formalizuota Europos Sąjungos Bendroji užsienio ir saugumo politika (BUSP), kurios struktūrose numatytas gynybinis matmuo ${ }^{17}$. Gynybinio matmens atsiradimą ES galima vertinti kaip europiečių atsaką ị amerikiečių kaltinimus dèl karinio nepajėgumo, be to, tai lèmè ir neišvengiamai gilejjanti ES integracija bei būtinybè vis augančiai ir stipréjančiai ES sukurti naujus karinius, gynybinius instrumentus, skirtus ES vertybėms bei interesams ginti. Šis pokytis buvo reikšmingas ES, kuri, reaguodama į tarptautinės aplinkos pokyčius ir prisiimdama karinio pobūdžio įsipareigojimus, tapo ne tik ekonomine - politine sajunga, bet kartu ir saugumo organizacija.

Po Maastrichto susitikimo kelerius metus gynybinès dimensijos kūrimas ES vyko vangiai. Iki 1998 m. nebuvo priimta jokių kardinalių sprendimų. Pagrindiniu veiksniu, stabdančiu tolesnį šios iniciatyvos vystymąsi, buvo ES valstybių nesutarimas dèl principinių bendros gynybos politikos ir bendros gynybos formavimo klausimų bei būsimų ES santykių su NATO. Tačiau 1998 m. gruodžio 3 - 4 d. St. Malo Didžiosios Britanijos bei Prancūzijos vadovų susitikime pasiektas susitarimas dèl ES nepriklausomų karinių pajègumų, kuriuos galima būtu panaudoti krizių atveju, kūrimo, ir tai tapo esminiu persilaužimu ES bendros gynybos politikos ir bendros gynybos formavimo procese.

1998 m. Kelno viršūnių taryba numatè VES funkcijas įtraukti į ES ${ }^{18}$, Helsinkyje pristatytas Pagrindinis tikslas (ang. Headline Goal) ir susitarta dèl Europos greito reagavimo pajègų (ang. Rapid Reaction Force $(R R F)$ įsteigimo. Europos greito reagavimo pajègu (EGRP) statusas buvo įtvirtintas $2000 \mathrm{~m}$. Nicos sutartyje ${ }^{19}$, o Lakene paskelbta, kad šos pajègos jau yra pajègios vykdyti kai kurias krizių valdymo operacijas $^{20} .2002$ m. gegužès 22 - 28 d. ES pirmą kartą ESGP struktūrose vykdė

\footnotetext{
${ }^{17}$ Bendra užsienio ir saugumo politika (BUSP) įtrauks visus klausimus, susijusius su ES saugumu, taip pat ir bendros gynybos politikos formavimą, kuri ilgainiui gali išaugti į bendrą gynybą. Treaty of $E U$, Maastricht, 1991, http://europe.eu.int/eur_lex/eu/treaties/index.html.

${ }^{18}$ Cologne European Council, Presidency Conclusions,1999, http://europe.eu.int/council/off/conclu/ index.htm.

${ }^{19}$ Treaty of Nice, Brussels, 14 February 2001, SN1247/1/01 REV1. Art.24(3), http://europa.eu.int/ comm./nice_treaty/index_en.htm.

${ }^{20}$ Leaken European Council Presidency Conclusions, 2001, http://europe.eu.int/council/off/conclu/ index.htm.
} 
savo krizių valdymo pratybas, kurios $2002 \mathrm{~m}$. Sevilijos viršūnių tarybos susitikime buvo pripažintos sėkmingomis. Nepaisant trūkumų, strateginio oro perkẻlimo, žvalgybinių sistemų, specialių operacijų, paieškos ir gelbejjimo bei apsaugos nuo cheminio, biologinio ir branduolinio ginklo srityse šios pajègos $2003 \mathrm{~m}$. gegužès mèn. buvo paskelbtos veiksniomis. Šiuo metu europiečiai jau perèmé vadovavimą operacijai Makedonijoje, o kitais metais EGRP, ko gero, pakeis NATO pajègas Bosnijoje ir Hercegovinoje. 2003 m. vasarą Konge pradèjo veikti ES misija ARTEMIS, kurią sudaro apie 1500 karių (dauguma prancūzų). Sios misijos tikslas - ginti civilius ir JT personalą, pagerinti humanitarinę situaciją, užtikrinti pabėgèlių stovyklų ir oro uosto saugumą, stabilizuoti saugumo situaciją Konge.

\section{Pagrindinis tikslas (Headline goal) ${ }^{21}$}

Iki 2003 m. ikurti Europos karines pajėgas, gebančias igyvendinti Petersbergo užduotis ${ }^{22}$. Šias pajégas turi sudaryti iki 15 brigadų: 50 000-60 000 karių, dislokuojamų krizės rajone ne ilgiau kaip per 60 dienų ir sugebančių veikti ten ne mažiau kaip vienus metus (be rotacijos).

EGRP ne tik išreiške europiečių siekị turèti karinius instrumentus, igalinančius geriau ginti ES narių interesus ir vertybes, - jos turejo tapti pirmosiomis naujo pobūdžio karinėmis pajëgomis, skirtomis kovoti su šiuolaikiniais konfliktais. Pakankamai greita EGRP evoliucija leido tikètis, kad, nors ir daug kritikuotas, šis europiečiu projektas bus sẻkmingai ịgyvendintas. Tačiau, siekiant įvertinti tolimesnes EGRP perspektyvas, verta atkreipti demesị i keletą svarbiu problemų, kurių vienoks arba kitoks sprendimas lems, ar šios pajëgos taps efektyvios, ar taip ir liks „popierinès“.

Viena pagrindinių EGRP problemų yra Petersbergo užduočių tiek teritorinis, tiek turinio neapibrèžtumas. Neišsprendus šios problemos, lieka neaišku, kur bus Europos karinių pajègų veikimo ribos ir kokio pobūdžio konfliktuose jos dalyvaus. ES gynybinių pajègumų panaudojimo scenarijai buvo svarstomi jau nuo 1995 m., o galimų operacijų nuotolis matuojant nuo Briuselio apibrèžiamas ,nuo $2000 \mathrm{iki} 6000 \mathrm{~km}$ “23. Vadinasi, trumpiausio nuotolio operacijos gali nesiekti išsiplètusios ES rytinių sienų, o tolimiausios operacijos vykti Afganistane, Vidurineje Azijoje ar Afrikoje. Toks neaiškus būsimų operacijų ribų apibrèžimas nesudaro galimybių tiksliai įvertinti kokių pajègų ir pajëgumų reikès būsimoms operacijoms.

Galima teigti, kad iš esmès būsimų misijų neapibrèžtumas sietinas su ES identiteto problema: kaip ES supranta save ir savo vertybes bei gintinus interesus. Kadangi dèl išsiskiriančių narių interesų ir nevienodo tarptautinio aktyvumo, ko gero, būtų sudètinga pateikti vienareikšmišką ES gintinų interesų sąrašą, verta atkreipti dėmesị i galimą ES vaidmenį tarptautinėje politikoje. Jei ES ateityje apsiribos regioniniu veikèjo vaidmeniu, tai Petersbergo užduotys apsiribos galimų vidinių pro-

${ }^{21}$ Helsinki European Council Presidency Conclusions, 1999, http://europe.eu.int/council/off/conclu/ index.htm

${ }^{22} 1992$ m. VES šalys pasiraše Petersbergo deklaraciją, patvirtinančią jų pasiryžimą suformuoti karinius vienetus, skirtus Petersbergo užduotims igyvendinti, kurios yra apibrež̌iamos taip: humanitarinès operacijos, gelbejjimo darbai, taikos palaikymas ir krizių valdymas,. http://europe.eu.int/ seadplus/leg/en/cig/g4000p.htm.

${ }^{23}$ Croft S., „Guaranteeing European Security?: Enlarging again“, International Affairs 78 (1), 2002, 102. 
blemų sprendimu arba stabilumo palaikymu geografiškai artimose erdvėse. Tačiau net šis scenarijus dèl vykstančios plètros bei dèl plètros priartėsiančių nestabilių regionų nepateikia aiškių būsimų operacijų rẻmų.

Kita vertus, ES šalys, būdamos vakarų civilizacijos atstovès, yra suinteresuotos vakarų liberaliosios demokratijos vertybių išsaugojimu ir plètra, todèl tikètina, kad Petersbergo tipo misijos bus vykdomos siekiant apginti šias vertybes. Vakaru civilizacijos vertybių gynyba gali nukelti EGRP ị tolimesnius regionus, pavyzdžiui, i Artimuosius rytus ar Afriką. Vis dèlto paskutiniaisiais metais šių vertybių gynybai ES buvo labiau linkusi naudoti ekonominius ar politinius instrumentus, o ne karinius, todèl ženklus perẻjimas prie karinių instrumentų bent jau artimiausiu metu yra mažai tikètinas.

Atsižvelgiant ị tai, kad ES ekonominė galia paverčia ją globalaus masto veikèju, verta atkreipti dėmesị ir ị globalaus ES vaidmens scenarijų. Šio scenarijaus atveju Petersbergo užduotys gali įtraukti veiksmus ir pakankamai nuo ES sienų nutolusiuose pasaulio regionuose. Tačiau kol kas šis scenarijus, ko gero, yra mažiausiai tikètinas. Pirmiausia dèl to, kad ES globali ekonominè galia nèra paremta atitinkama politine įtaka ir kariniais pajëgumas, antra, kol kas pati ES nèra suinteresuota globaliu vaidmeniu, ir, be to, globaliu ES interesų gynyba galima tik tuo atveju, jei šie interesai visų narių yra suvokiami taip pat, tačiau kol kas jie labai skiriasi. Artimiausiu laikotarpiu labiausiai tikètinas yra regioninio veikèjo scenarijus, nes, prieš pradèdama veikti globaliu mastu, ES dar turi išspręsti tam tikras vidaus bei regiono problemas. Kita vertus, tolimesnèje perspektyvoje sẻkminga plètra ir integracija neabejotinai gali sąlygoti globalesnes ambicijas.

Petersbergo užduočių turinys taip pat nepateikia aiškaus atsakymo ị tai, kokias operacijas turètų vykdyti EGRP. Dabartinis Petersbergo užduočių apibrėžimas suteikia galimybes net tokius didelio masto konfliktus, kaip İlankos karas ar šeštajame dešimtmetyje vykęs Korèjos karas, vertinti kaip atitinkančius apibrėžimo turinị. Todèl tikètina, kad būsimujų EGRP misijų turinị lems pačios ES pasirinkimas: sprendžiant tarptautinio saugumo problemas prioritetas bus teikiamas karinei ar civilinei ES rolei.

Henrik Larsen teigia, kad tarptautinių konfliktų sprendimo samprata ES yra sietina su liberaliaja doktrina ir joje akcentuojamais demokratijos, pagarbos žmogaus teisėms ir pagrindinėms laisvėms bei teisės viršenybės principais ${ }^{24}$. Tarptautinių konfliktų priežastis ES narès dažniausiai sieja su šių principų pažeidimu ir mano, kad jų ištaisymas išspręstų daugumą šiandien vykstančių konfliktų. Pavyzdžiui, terorizmą ES dažniausiai apibrěžia kaip ekonominę, politinę ir socialinę problemą, reikalaujančią atitinkamų sprendimo priemonių, o JAV terorizmą laiko karine grèsme, su kuria reikia kovoti karinėmis priemonėmis. Todẻl savo ị misiją - užtikrinti tarptautinị saugumą ir atsakyti ị šiuolaikinius saugumo iššūkius - ES žvelgia kaip civilinis veikejjas. 2002 m. vasario 19 d. savo kalboje J. Solana pabrèžè, kad „pasaulio stabilumas - labiau civilinè nei karinè sąvoka“, o pagrindinis Europos siekis - tapti „civiline galia“. Jo manymu, viena iš svarbiausių saugumo ir stabilumo garantijų - tai integracijos tąsa ir sèkminga plètra ${ }^{25}$.

${ }^{24}$ Larsen H., „The EU: A Global Military Actor“, Cooperation and conflict, Journal of the Nordic International Studies Association, SAGE publications, Vol. 37, N. 3, September 2002, 291.

${ }^{25}$ Ten pat, 298. 
Tiesa, kaimyninių šalių problemų sprendimą ES šalys supranta kaip specifinę ES politinės atsakomybės sritį. ES įsipareigojimus Balkanuose ir jų sẻkmę valstybės narès tiesiogiai sieja su savo saugumu, o šiuos ịsipareigojimus įgyvendina naudodamos ir karinius instrumentus. Tačiau karines priemones ES šalys suvokia tik kaip vieną ir, ko gero, ne patị svarbiausią saugumo problemų sprendimo instrumentą, todèl jas įtraukia ị platų politinių ir ekonominių konfliktų sprendimo priemonių tinklą. Christopher Patten, kalbẻdamas apie pasikeitusią saugumo problematiką, tvirtino, kad „protingosios“ bombos yra svarbios, tačiau dar svarbesnè yra protinga pagalba vystymuisi. Svarbesnis yra siekis ị tarptautinę bendruomenę valstybes įtraukti, nei jas išstumti“"26. Panašǔs motyvai skambejo ir 2003 m. birželio $20 \mathrm{~d}$. Salonikuose J. Solana pristatytoje naujoje ES saugumo strategijoje „Saugesnè Europa geresniame pasaulyje" (ang. A Secure Europe in a Better World) ${ }^{27}$. Čia buvo akcentuojamos trys pagrindinés temos: pirma, užtikrinti daugiau išteklių kuriant ekonominị ir politinị stabilumą kaimynysteje; antra, kurti tarptautinę tvarką, paremtą daugiaesiškumu; trečia, stiprinti civilinius ir karinius pajègumus kovojant su masinio naikinimo ginklų grèsme ir „piktavalèmis“valstybėmis. Civiliniams instrumentams J. Solana skyrè ypatingą dėmesị. Dokumente buvo užsiminta ir apie prevencinius veiksmus, tačiau ir čia daugiau dèmesio buvo skiriama daugiašališkumui užtikrinti, o ne kariniams prevenciniams veiksmams.

Ivvertinus tai, kad šiandien ES pagrindinị dėmesį teikia regioninèms problemoms ir siekia jas spręsti pirmiausiai civilinėmis priemonėmis, karininius pajègumus naudojant tik kaip vieną iš civilinio saugumo užtikrinimo priemonių komplekso sudètinę dali, tikètina, kad artimiausiu laiku Petersbergo užduotys bus apibrěžiamos kaip labai nedidelio masto taikos palaikymo operacijos Europoje arba netoli nuo Europos nutolusiuose regionuose.

Petersbergo užduočių neapibrèžtumo problema tiesiogiai siejasi su kitu svarbiu veiksniu, lemsiančiu EGRP sẻkmę ar nesèkmę, - ES šalių kariniais pajėgumais. Nors dauguma EGRP tyrinètojų teigia, kad ši problema ir yra pagrindinè, tačiau iš tiesų šios problemos aktualumą lems Petersbergo užduočiu apibrèžimo pasirinkimas. Karinių pajėgumų problema nebus tokia akivaizdi, jei ES šalys pasirinks siauriausią Petersbergo užduočių apibrèžimą.

Europos kariniu pajëgumu trūkumai išryškèjo Balkanu konfliktu metu. Buvusio JAV Gynybos sekretoriaus William S. Cohen ir generolo Henry H. Schelton JAV Senato Ginkluotujų pajègų komitetui pateiktame pranešime JAV ir Europos sajungininkų bendras darbas Kosove susilaukè negatyvaus ịvertinimo ${ }^{28}$. Nustatę esmines problemas, amerikiečiai reziumavo, kad europiečiai susiduria su dideliais sunkumais dèl mobilumo, vadovavimo, kontrolès ir komunikacijos nepakankamo efektyvumo. Balkanų konfliktai išryškino trūkumus strateginès žvalgybos, priešraketinès gynybos, strateginio transportavimo oro pajėgumų, tikslaus valdymo raketų bei

\footnotetext{
${ }^{26}$ Freedland J., „Patten Lays into Bush's America“, The Guardian, 9 February, 2002.

${ }^{27}$ Solana J. „A Secure Europe in a Better World, Thessaloniki“ 20 March 2003, http://ue.eu.int/ pressdata/EN/reports/76255.pdf. 2003 m. gruodžio 12 d. Briuselyje ši strategija patvirtinta Europos viršūniu taryboje.

${ }^{28}$ Smith I. D., Shadow Secretary of State for Defense, United Kingdom to the Committee on International Relations, House of Representatives, Wednesday, 10 November, 1999.
} 
kitose srityse, sietinose su modernia technologija. Nors dauguma šių pajëgumų yra aktualesni teritorinès gynybos operacijose ir todėl jų nepakankamumas gali ir neturèti lemiamos įtakos operacijų Petersbergo užduočių rėmuose efektyvumui, tačiau jei ES imsis ambicingesnių užduočių toliau nutolusiose teritorijose, šie pajëgumai bus būtini. ES karinio komiteto pirmininkas teigè, kad kol EGRP nebus pajègios užtikrinti efektyvaus transportavimo oru (iki $2008-2012 \mathrm{~m}$.) tol pirmas A400M nebus paruoštas veikti, nepajëgs vykdyti sudėtingesnių misijų.

Galima teigti, kad pajëgumų problema buvo lyg užprogramuota jau nustatant $\mathrm{Pa}$ grindinị tikslą, kai europiečiai nepakankamai apskaičiavo realias jo igyvendinimo galimybes. Atsižvelgiant ị tai, kad kai kurios misijos gali užsitęsti arba kad ES gali dalyvauti keliose misijose iš karto, EGRP turi būti pajëgios rotuotis. Siekdama imtis ambicingesnių misijų, ES privalès turèti tris ar keturis kartus daugiau nei parengtyje esančios numatytos 60000 pajëgos. Realus reikalingų karių skaičius gali išaugti iki 200 000, atitinkamai padidès ir reikalingos karinès technikos, logistikos ir kt. pajëgumų apimtys. Ir nors $2001 \mathrm{~m}$. lapkričio mèn. vykusioje ES gynybos ministrų konferencijoje ES narès susitare padindinti savo įnašus, realios galimybės suteikti šiuos pajëgumus yra diskutuotinos.

Dar vienas veiksnys, kuris ne tik lemia ES karinio sektoriaus atsilikimą, bet ir didina ES šalių priklausomybę nuo JAV, - Europos karinės pramonės problemos. Fragmentuota karinès pramonės struktūra, konkuruojantys šalių interesai bei rinkos nepakankamumas mažina europiečių galimybes šioje srityje konkuruoti su amerikiečiais ir taip pat EGRP autonomiškumą. Nors minimalūs bendradarbiavimo pagrindai karinès pramonès srityje padèti dar Šaltojo karo metais: įsteigta Europos grupè, Nepriklausoma Europos programų grupè, kuri 1992 m. performuota į Vakarų ginkluotès grupę (VES struktūrose) ${ }^{29}$. Ir nors visos ES narès pripažįsta, kad, siekiant efektyvumo, būtina bendradarbiauti, vis dèlto glaudesnị bendradarbiavimą stabdo tai, kad né viena jų nenori visiškai atsisakyti savo interesų.

Paskutiniaisiais metais Europos karinès pramonès srityje galima įžvelgti ir pozityvių tendencijų. Dèl padidejusios konkurencijose Europoje, susijusios su JAV kompanijų atèjimu ị Europos rinkas, ES šalyse prasidejjo nacionalinių firmų susiliejimai, kartais įtraukiant ir užsienio (ES šalių) kompanijas. 2002 m. Britanija, Prancūzija, Vokietija ir Italija ịsteige Bendrą organizaciją bendradarbiavimui ginkluotės srityje (OCCAR), igyvendinsiančią bendras pirkimų programas bei iggalintą sudaryti bendrus kontaktus; Ispanija ir Švedija 1998 m. pasirašè ketinimų protokolą, skirtą koordinuoti ir derinti kai kurias gynybos politikos sritis bei procedūras.

Vienas iš galimų sprendimų, sudarysiančių galimybes pakelti ES karinès pramonès funkcionalumą bei efektyvumą, - tai techninių operacijų reikalavimų harmonizavimas bei komercinių interesų suderinimas, kuris jau buvo atliktas aviacinès ir kosmoso pramonès srityse. Tikètina, kad tarpvalstybinès programos - bendra britų vokiečių ivairaus naudojimo karinio transporto priemonių programa (ang. Joint British German Multi Role Armared Vehicle Program), Horizon oro gynybos programa, Tiger ir NH90 sraigtasparnių programa, bendradarbiavimas transportavimo oro pajëgumų srityje (A400M oro transporteris) $)^{30}$ - bus impulsas plètoti ir restruktūrizuoti

${ }^{29}$ Cornish, (note 4), 105.

${ }^{30}$ „Europe in Space: Overtaking the Cold Warriors“ 1900 GMT, 19 April 200, http:// www.stratfor.com 
bendrą Europos karinę pramonę. Europos ginklų, tyrimų ir karinių pajėgumų agentūros įsteigimas, siūlomas ES Konstitucijos projekte, neabejotinai paskatintų ES karinių pajègumų didinimą ir sąveikumą bei stiprintų ES gynybos pramonès bazę, tačiau valstybès narès baiminasi, kad ši agentūra, nustatydama ginkluotès ịsigijimo principus ir prioritetus, gali pakenkti šalies interesams arba jau egzistuojantiems prekybiniams santykiams su trečiosiomis valstybėmis.

EGRP ateitis priklausys ir nuo to, ar pavyks ES šalims užtikrinti pakankamą karinių pajègų bei operacijų finansavimą. Lyginant su JAV, Europos šalys ne tik išleidžia gynybai mažiau, - šios lešos naudojamos ne taip efektyviai. Didesnè dalis ES valstybėse gynybai skiriamų lèšu yra išleidžiamos kariuomenėms išlaikyti, o ne modernių karinių technologijų vystymui, kaip tai daro JAV. Nepakankamas ir ne visiškai efektyvus karinių pajëgų finansavimas gali nulemti tai, kad ir taip jau susiduriančios su dideliais trūkumai ES karinès pajègos bus nepajègios atlikti net ribotų užduočių.

Operacijų finansavimas taip pat svarbus veiksnys EGRP perspektyvoms. Lètos finansavimo procedūros gali sulètinti operacijos eigą, o ribotų finansavimo galimybių išryškẻjimas misijai jau prasidèjus ar užsitęsus būtų labai pavojingas ne tik karių, bet ir regiono, kuriame misija yra vykdoma, saugumui ir stabilumui. Finansiniu aspektu ES yra skiriamos dvi krizių valdymo rūšys: civilinė, kurios finansavimas numatytas ES biudžete, ir karinio pobūdžio operacijos, kurios finansuojamos ad hoc pagrindu. Iš ES biudžeto finansuojamos tik Petersbergo užduočių administracinès, logistinès bei medicininès išlaidos. Visas kitas išlaidas turi padengti valstybès narès pagal NATO naudojamą principą, kai moka operacijoje dalyvaujančios šalys ${ }^{31}$. Šis principas neblogai veikia NATO, tačiau ES galiojantis „konstruktyvaus susilaikymo" principas $^{32}$ gali sąlygoti išsisukinėjimą (ang. free riding). Problemiška yra ir tai, kad Petersbergo užduočių vykdymas reikalauja labai ịvairių priemonių, kurios yra įtrauktos ị skirtingus ES ramsčius, ir todèl skiriasi šių priemonių finansavimo procedūros ir šaltiniai ${ }^{33}$. Procedūrų ir šaltinių įvairovè neabejotinai lètina finansavimo procesą ir mažina misijos operatyvumą. Kita vertus, sudètinga garantuoti, kad reikiamu momentu bus gautos visos reikalingos lěšos. Operacijų finansavimo problemos gali sumažinti operacijų ir karinių pajègų pasirengimo greitị, sutrumpinti misijos laiką, sąlygoti netolygų kaštu pasidalijimą, kai didžiosioms valstybėms teks liūto dalis išlaidų tiek personalo, tiek finansų prasme. Komplikuota karinių operaciju finansavimo procedūra, kai, sprendžiant konfliktus, daug lengviau galima pasinaudoti civilinėmis, o ne karinèmis krizių valdymo priemonèmis, ko gero, dar kartą įrodo, kokiems konfliktų sprendimo instrumentams ES yra teikiamas prioritetas.

Karinių pajëgumų trūkumą esant politinei valiai ir produktyvioms pastangoms galima ištaisyti per tam tikrą laiką, bet išspręsti išsiskiriančių nacionaliniu interesų keliamas problemas sudètingiau. Pagrindiniai nesutarimai kyla dèl skirtingo šalių požiūrio ị santykius su JAV bei ị pačios ES formą - tai turi būti federacija ar

\footnotetext{
${ }^{31}$ Missiroli A., „Euros for ESDP: financing EU operations“, Occasional Paper N. 45, June 2003, European Union Institute for Security Studies, Paris.

${ }_{32}$ Amsterdamo sutartyje numatytas „konstruktyvaus susilaikymo“ principas (ang. constructive abstention), leidžiantis šalims, kurių interesai gali būti pažeisti, susilaikyti priimant sprendimus ir nedalyvauti veiksmuose, neblokuojant sprendimo priëmimo.

${ }^{33}$ Missiroli, (note 31).
} 
konfederacija. Jei ES narés nesutaria net dèl bendros EGRP, ateityje joms gali būti dar sudètingiau susitarti dèl to, kada, kaip ir kur ESGP turi būti naudojamos. Siekiant užtikrinti vieningą $E S$ gynybos politiką, reikalingas tvirtas institucinis pagrindas, suteikiantis prielaidas skirtingų šalių interesų derinimui ir ịpareigojantis laikytis prisiimtų įsipareigojimų. Tačiau ES BUSP, kurios dalis yra EGRP, įtvirtinti tarpvyriausybiškumo ir vienbalsiškumo principai nesuteikia pagrindo konsoliduoti besiskiriančius valstybių narių interesus. Daugumos balsavimo principo ịvedimas į BUSP teigiamai lemtų EGRP efektyvumą, tačiau valstybès narès, bijodamos, kad daugumos balsavimo procedūros naudojimas svarbias užsienio ir saugumo politikos klausimais gali pažeisti jų nacionalinius interesus, nèra linkusios atsisakyti vienbalsiškumo.

Naujų narių ịsijungimas ị ES gali dar labiau komplikuoti galimybes susitarti EGRP klausimais. Pirma, kad šios šalys labai skiriasi nuo daugumos senbuvių tiek savo ekonominiu pajëgumu, tiek labai atsargiu požiūriu ị suvereniteto klausimus, be to, joms būdinga proatlantinè pozicija. Kita vertus, ES sienos priartės prie probleminių regionų galimų EGRP misijų apibrèžimas neabejotinai plèsis, tačiau neaišku, ar naujų narių interesų gynyba bus suinteresuotos senosios narès, ir atvirkščiai.

Buvo bandymų inicijuoti principų ESGP klausimais panaikinimą naujoje Konstitucijoje, Konstitucijos projekte krizių atveju (įskaitant sprendimų vykdyti Petersbergo užduotis prièmimą) pagrindinis vaidmuo vèl numatytas Europos Tarybai, kurioje sprendimai bus priimami vienbalsiai.

ES Konstitucijos projekte numatyti ir kiti patobulinimai, susiję su ESGP: plèsti Petersbergo užduočių apibrēžimą, itraukiant nusiginklavimo, karinių ekspertų pagalbą, konfliktinès stabilizacijos ir kovos su terorizmu funkcijas (ir paramą trečiosioms šalims kovojant su terorizmu jų teritorijose); įtraukti struktūruoto bendradarbiavimo principą, leidžiantị kelioms šalims glaudžiai bendradarbiauti gynybos srityje; užtikrinti ad hoc koalicijoms veikiančioms ES struktūrose galimybę vykdyti operacijas ES vardu; įrašyti solidarumo išlygą (ES šaliu pagalba viena kitai teroristinio išpuolio, gamtinès arba žmogaus sukeltos katastrofos atveju); sukurti Europos ginkluotės, tyrimų ir karinių pajègumų agentūrą ${ }^{34}$. Nors šios Konstitucijos projekte numatytos nuostatos padètų išspręsti kai kurias EGRP problemas, tačiau diskusijose dẻl naujos Konstitucijos išryškejjo nesuderinamumo problema: šalys turejjo labai skirtingas EGRP sampratą ir joms sunkiai sekèsi susitarti. Sprendimą dèl Konstitucijos priims ne tik seni nariai, bet ir naujai ịsijungusios į ES šalys, kurios taip pat turi savo EGRP viziją, todèl gali kilti dar daugiau nesutarimų dèl pasiūlytų Konstitucijos nuostatų.

ES šalių nesutarimus EGRP kūrimo klausimais parodè 2003 m. balandžio 29 d. Briuselyje ịvykęs keturių ES šalių (Prancūzijos, Vokietijos, Belgijos ir Liuksemburgo) vadovų susitikimas dèl bendradarbiavimo gynybos srityje. Susitikimo pabaigoje šalys išplatino pranešimą, kuriame pateikè pasiūlymus naujajai ES Konstitucijai. Buvo siūloma ES Konstitucijoje ịvesti solidarumo ir kolektyvinès gynybos bei struktūruoto bendradarbiavimo principus, išplèsti Petersbergo misijų formuluotę, įtraukiant galimybę ES vykdyti visų tipų operacijas (nuo taikos iki kovinių operacijų), sukurti ginkluotės įsigijimų agentūrą ir atskirą nuo NATO ir valsty-

\footnotetext{
34 „Draft Treaty Establishing a Constitution for Europe“, Brussels, 18 July 2003, http:// www.european-convention.eu.int/bienvenue.asp?lang=EN.
} 
bių narių ES štabą, suteikiantị galimybę atskiroms šalims sparčiau integruotis gynybos srityje $^{35}$.

Kai kurie ketverto pasiūlymai kitų narių buvo sutikti atsargiai, o kai kurios iš jų atvirai išreiškè savo nepasitenkinimą ir nuogąstavimus. Italijos ir Didžiosios Britanijos pareigūnai buvo skeptiškai nusiteikę šių pasiūlymų atžvilgiu ir baiminosi, kad panašūs veiksmai gali susilpninti transatlantinị ryšį. ES institucijų atstovai taip pat neskubèjo sveikinti iniciatyvos. J. Solana, kalbėdamas apie susitikimą, pabrèžè, kad ,jei šio susitikimo tikslas yra skatinti Europos valstybes skirti daugiau lèšų kariniu pajègų vystymui, tai susitikimas yra vertingas visai ES ${ }^{\text {“36 }}$, tačiau né žodžiu neužsiminè apie kitus pasiūlymus. R. Prodi pabrèžè, kad remia iniciatyvą tiek, kiek ji yra atvira kitiems nariams. Tony Blair sukritikavo ketverto pasiūlymus teigdamas, kad britai nerems jokių veiksmų, galinčių pakenkti NATO ar prieštaraujančių pagrindiniams jau sutartiems Europos gynybos principams. Jis netgi perspejo dèl galimų naujų Saltojo karo pobūdžio pasidalijimų, jei transatlantinis ryšys silpnès ${ }^{37}$.

Jungtinès Karalystès, Ispanijos, Portugalijos, Italijos, Danijos ir Nyderlandu pozicija buvo vienareikšmiška: kolektyvinès gynybos sritis turi būti palikta NATO kompetencijai. Dar keturios ES narès (Suomija, Švedija, Airija ir Austrija) bei dvi kandidatès (Malta ir Kipras) laikosi nesijungimo ị karinius aljansus politikos ir todèl, ko gero, nepritars kolektyvinès gynybos sistemos ES viduje kūrimui. Būsimos ES narès, tarp jų ir Lietuva, pasisako už transatlantinio ryšio išlaikymą ir gynybos planavimo prioritetą taip pat teikia NATO. Pagaliau tai, kad susitikime nedalyvavo ES atstovai, parodè, kad ši iniciatyva nèra susijusi su oficialiaja Europos saugumo ir gynybos politika. Taigi nors ketverto nariai buvo nusiteikę rimtai kovoti dẻl savo pasiūlymų Konvente sprendžiant Europos ateitį, kai kurie iš jų greičiausiai jie nebus priimti. Kita vertus, tikètina, kad Prancūzija ir Vokietija, siekdamos pagerinti dẻl Irako karo pašlijusius santykius su JAV, pačios nebus suinteresuotos eskaluoti Vašingtonui nepriimtinų klausimų.

$2003 \mathrm{~m}$. EGRP pajegos buvo paskelbtos veiksniomis ir jau vykdo misijas Makedonijoje bei Kongo Demokratinejje Respublikoje. Šios misijos yra labai nedidelès ir nesudètingos, tačiau europiečiams ypač svarbu gerai pasirodyti jose. Visų pirma dèl to, kad atgautų amerikiečių pasitikéjimą, antra, jog įrodytų pasauliui, kad Europos politinė bei ekonominè galia yra paremta realiais kariniais instrumentais. Pagaliau nuo europiečių sèkmės šiose misijose neabejotinai priklausys EGRP ịvaizdis bei tolimesnès veiklos perspektyvos.

Nors svarbu ir tai, kaip europiečiams pavyks išspręsti institucines ir pajëgumų problemas, tačiau, ko gero, svarbiau nei institucijos ir pajègumai yra ES narių suinteresuotumas EGRP kūrimu. Šalys nèra linkusios rizikuoti savo karių gyvybėmis, jei šiai rizikai nèra pakankamo pagrindo, suderinamo su svarbiausiais šalies interesais. Kyla klausimas, ar ES narės yra pasirengusios rizikuoti savo karių gyvybėmis dèl Europos. Jei reikètų atsakyti ị șį klausimą dabar, ko gero, daugumos šalių pozicijos būtų

35 „Meeting of the Heads of State and Government of Germany, France, Luxembourg and Belgium on European Defence“,Brussels, 29 April 2003, http://www.dgap.org/english/tip/tip0302/ ge_fr_lu_be290403.htm.

${ }^{36}$ Lobjakas A., „EU: Defense 'Mini - Summit' Highlights Unease With U.S. Dominance“, http:// www.rferl.org/nca/features/2003/04/29042003164338.asp.

37 Ten pat. 
neigiamos. Taigi tikrasis iššūkis kuriant EGRP - ne tik efektyvios karinès struktūros, paremtos realiais pajègumais, bet taip pat sugebẻjimas užtikrinti politinę valią. Ir galbūt šiuo atžvilgiu svarbesnès yra ne balsavimo procedūros, o politinès ir institucinès kultūros, skatinančios ES nares savo nacionalinius interesus apibrěžti ES perspektyvoje, kūrimas.

EGRP projektas neįmanomas ir be efektyvios BUSP, šalys privalo turèti ne tik bendrą EGRP ir jų naudojimo viziją, bet taip pat apsispręsti dẻl šių pajėgų vietos regiono saugumo struktūroje bei santykių su kitomis tarptautinėmis organizacijomis, ypač dẻl santykių su NATO. Didžioji dalis ES narių pagrindinę rolę regiono saugumo struktūroje teikia būtent šiai organizacijai ir savo karines pajëgas ES struktūrose sutiks dislokuoti tik tada, jei NATO atsisakys dalyvauti. Tokia situacija sąlygoja daug neaiškumų dèl būsimų EGRP misijų. Problemiška ir tai, kad ES ir NATO iš esmès naudosis tomis pačiomis pajègomis (vykdydami platesnio pobūdžio karines operacijas, europiečiai susiduria su pajëgumų problemomis ir tai vers juos naudotis NATO pajėgumais). Akivaizdu, kad EGRP bus priklausomos nuo NATO.

EGRP vystymasis artimiausiu metu dèl ES gilejančios integracijos ir plètros gali dar sulètėti. Tačiau jei šie procesai bus sėkmingi, tikètina, kad darys teigiamą ątaką ERGP perspektyvoms ateityje. Pavyzdžiui žymus ES tyrinètojas Donald Puchala optimistiškai vertina bendros ES saugumo ir gynybos politikos, o kartu ir EGRP perspektyvas. Jis yra įsitikinęs, kad jei europiečiai kažko imasi, tai jie anksčiau ar vèliau tai ịvykdys. Savo straipsnyje „Taikos kūrimas iš gabaliukų: Europos vienybės perspektyvos“ (ang. Building Peace in Pieces: the Promise of European Unity) ${ }^{38}$ jis teigia, kad beveik kiekviena krize ES sąlygodavo gilesnę organizacijos integraciją arba plètrą. Sis procesas visada susidurdavo su stipria opozicija, sąlygojančia konfrontaciją, derybas, kompromisus ir, pagaliau, didèjančią vienybę. O su kiekviena sẻkminga sinteze ES vienybė stiprèjo. Išanalizavus ES evoliucijos istoriją, galima pastebèti, kad beveik kiekvienas didesnis tikslas, kurị ES narès užsibrèžia ịgyvendinti, anksčiau ar vèliau yra pasiekiamas. Taigi nors tikètina, kad artimiausiu metu ES greičiausiai rinksis regioninio veikejjo vaidmenį, tikètina, kad, laikui bėgant, jos ambicijos taps globalesnėmis. Vis dėlto lieka neaišku, kaip ES nuspręs remti globalią veiklą - karinèmis ar civilinėmis priemonemis. Nuo to taip pat priklausys EGRP forma ir perspektyvos.

\section{NRP ir EGRP: bendradarbiavimo perspektyvos ir galimos problemos}

Po Šaltojo karo vienu svarbiausių saugumo struktūrųžemėlapio akcentu tapo tarporganizacinis bendradarbiavimas ${ }^{39}$, kai skirtingos tarptautinès organizacijos užtikrina įvairaus pobūdžio saugumo instrumentus, reikalingus visuose saugumo politikos matmenyse. ES nepajëgumas veikti sudètingesnèse misijose be NATO paramos, daugumos ES narių priklausymas NATO organizacijai, abiejų organizacijų ko-

${ }^{38}$ Puchala D., „Building Peace in Pieces: the Promise of European Unity“, in Kegley Ch. W., Wittkopf E. R. ed., The Global Agenda: Issues and Perspectives, Boston: McGraw-Hill, 1998, 171.

${ }^{39}$ Winn N., „Europe: Old Institutions, New Challenges“ in Jones C., Kennedy-Pipe C., ed., International Security in a Global Age: Securing the Twenty - first Century, London, Portland: Frank Cass Or., 2000, 80. 
va dèl to paties tikslo - demokratijos ịsigalèjimo ir saugumo bei stabilumo pasaulyje bei daugelis kitų istorinių, politinių, ekonominių ir kultūrinių priežasčių lemia, jog bendradarbiavimas tarp šiu dviejų organizacijų yra neišvengiamas.

NATO ir ES bendradarbiavimo karinèje srityje priešistore galima būtų įvardinti santykius, egzistavusius tarp Šiaurès Atlanto Aljanso ir Vakarų Europos Sajungos (VES). Modifikuotos Briuselio sutarties 4 str. ipareigojo sutarties šalis ir visus pagal sutartį sukurtus organus dirbti glaudžiai bendradarbiaujant su NATO, remiantis NATO karine vadovybe, informaciniais pajègumais ir konsultuotis su NATO kariniais klausimais ${ }^{40}$. Susitarimai ir sarangos, sudarytos tarp NATO ir VES nuo $1991 \mathrm{iki} 2000 \mathrm{~m}$., padejo pagrindus tolimesnès strateginès partnerystès tarp NATO ir ES plètotei.

ES perėmus VES funkcijas, reikėjo iš naujo nustatyti NATO ir ES ateities santykių gaires. Sprendimas buvo pasiūlytas Vašingtono viršūnių susitikime ${ }^{41}$, pagal kuri abi organizacijos turèjo bendradarbiauti NATO ir VES bendradarbiavimo patirties pavyzdžiu. $2000 \mathrm{~m}$. liepos mèn. prasidėjo reguliarios išankstinès diskusijos dèl bendradarbiavimo. O Nicos viršūnių taryboje buvo patvirtintos nuolatinès NATO ir ES bendradarbiavimo struktūros. Svarbiausias bendradarbiavimo tarp ES ir NATO akcentas, ko gero, buvo ES priëjimas prie NATO vadovavimo, planavimo ir kitu pajėgumų. Nicos viršūnių tarybos susitikime šị prièjimą buvo numatyta užtikrinti pagal „Berlin plus“42 formulę. Nors 2000 m. gruodžio $14-15$ d. vykusiame NATO gynybos ministrų susitikime dauguma šalių pritare Nicoje numatytoms ES-NATO bendradarbiavimo struktūroms, sprendimas nebuvo priimtas, nes Turkija, baimindamasi, kad ES pajègos nebūtų panaudotos prieš jos interesus, pavyzdžiui, Kipre, vetavo iniciatyvą SAT. Abejonių dęl NATO ir ES bendradarbiavimo turëjo ir Graikija. Turkijos bei Graikijos dvejonès užtęsè šio prièjimo patvirtinimą dar dvejiems metams, kol susitarimas pagaliau buvo pasiektas Kopenhagos viršūnių tarybos susitikime. Kopenhagoje Turkijai pavyko išsiderèti nuostatą, jog ES krizių valdymo operacijose dalyvaus tik tos ES valstybès, kurios yra ir NATO narès ar partnerès, taigi buvo išstumtos Malta ir Kipras. 2002 m. gruodžio 13 d. NATO ir ES paskelbẻ bendrą Deklaraciją dèl ESGP ${ }^{43}$. Ji nubrèžè formalius ES - NATO bendradarbiavimo politinius principus ir suteike ES garantuotą priëjimą prie NATO planavimo (ES naudosis operaciniu planavimu SHAPE ir NATO pajëgu planavimo procesu) ir logistiniu pajègumų krizių valdymo, konfliktų prevencijos atveju. Abiem organizacijoms svarbus buvo ir VES deklaracijose, pridètose prie Maastrichto ir Amsterdamo sutarčių,

${ }^{40}$ Modified Brussels Treaty, Brussels, 1954, http://www.weu.int/Treaty.htm.

${ }^{41}$ Washington Summit Communiqué „, An Alliance for the 21st Century“, issued by the Heads of State and Government participating in the meeting of the North Atlantic Council, Washington, D.C., 24 April 1999, http://www.nato.int/docu/pr/1999/p99-064e.htm.

421996 m. Berlyne buvo priimti sprendimai suteikti NATO paramą VES vadovaujamoms operacijoms (Berlyno Komunikatas). 1999 m. šis susitarimas buvo patobulintas „Berlin plus“ formule - šis paketas ịtrauke 4 elementus: 1) garantavo ES dalyvavimą planuojant NATO operacijas; 2) numate ES galimybe naudotis NATO pajègumais; 3) patvirtino NATO Europos vadovavimo struktūru panaudojimo ES vadovaujamose operacijose galimybę (taip pat ir Sajungininkų pajėgų Europoje vyriausiojo vado (SACEUR) dalyvavimą); 4) įsipareigojo pritaikyti NATO gynybos sistemą ES operacijoms skirtų pajėgu įtraukimui. Http://www.nato.int/uk.docu/esdi.htm.

43 „EU-NATO Declaration on ESDP“, 13 December 2002, http://www.nato.int/docu/pr/2002/ p02-142e.htm. 
nustatytas NATO pirmumo principas ${ }^{44}$, kuris patvirtintas Nicos viršūnių taryboje ir NATO ir ES Deklaracijoje dėl ESGP. Tai reiškè, kad EGRP dalyvaus kariniuose veiksmuose tik tada kai NATO atsisakys dalyvauti.

NATO ir ES Deklaracija dèl ESGP bei sutartis tarp ES ir NATO dèl informacijos saugumo, igalinusi abi puses keistis įslaptintais dokumentais, tapo pagrindu 2003 m. kovo 31 d. ES perimti iš NATO misiją Makedonijoje ir patvirtino šių dvieju organizacijų strateginę partnerystę. Vis dẻlto kyla klausimas, ar susitarimai tarp ES ir NATO reiškia, kad šios organizacijos pasidalijo funkcijomis užtikrinant saugumą ir stabilumą pasaulyje? Ir, jei taip, kokios rolès buvo numatytos EGRP ir NRP? Pagaliau įdomu, ar bendradarbiavimo schema numatyta „Berlin plus“ formuleje yra įgyvendinama praktiškai.

Buvęs NATO Generalinis sekretorius G. Robertson pabrěžè, kad pagrindinis NATO tikslas - užtikrinti kad NRP ir EGRP papildytų viena kitą. Generalinis sekretorius ịsitikinęs, kad šios pajëgos nedubliuos viena kitos ir galètų puikiai bendradarbiauti. Jis teige, kad EGRP nuo NRP skiriasi tuo, kad jose nedalyvaus amerikiečiai kariai, taip pat ir tuo, kad abi turi skirtingus tikslus: ERGP pajègų pagrindinis tikslas - vykdyti Petersbergo užduotis, o NATO naujujų pajègų misija - ,gesinti gaisrus pasaulio karštuosiuose taškuose “45. Generolas Gustav Hägglund, ES Karinio komiteto pirmininkas, savo vizito Suomijoje metu kalbėdamas apie šiandienines saugumo problemas akcentavo, kad kai reikia greitų veiksmų, ES yra neiggali - trūksta reikalingos organizacijos. Tokiose situacijose NRP tikslas - užtikrinti greitus ir efektyvius veiksmus. Jei reikès, ES galès prisiimti atsakomybę tolesniuose veiksmuose $^{46} .2002$ m. NATO ir ES Deklaracijoje dèl ESGP taip pat pripažistama, kad organizacijos yra skirtingos prigimties, ir pabrěžiama, kad ES dalyvaus tik tose srityse, kuriose NATO kolektyviai nedalyvaus. Akivaizdu, kad NATO ir ES kuriamos pajëgos yra skirtingos prigimties, kad joms numatytos skirtingos funkcijos, ir tikètina, kad jos viena kitos nedubliuos. Kita vertus, nors pasiskirstymas darbais tarp ES ir NATO būtų racionalus sprendimas, lieka neaišku, ar jis yra ịgyvendinamas praktiškai ir ar tuo suinteresuotos visos dalyvaujančios šalys.

EGRP kol kas yra pajègios atlikti tik labai riboto pobūdžio operacijas ir neaišku, kaip toliau evoliucionuos. NRP taip pat tėra tik projektas. Nustatyti realias ju bendradarbiavimo galimybes, kol nèra praktinès šių pajėgų veiklos įrodymų, yra labai sudėtinga. Vis dèlto jau aiškejja pagrindinès problemos, galinčios sutrukdyti bendrai šių pajègų veiklai. Svarbiausias problemas, kaip ir NRP ir EGRP atvejais atskirai, ko gero, būtų galima suskirstyti ị du blokus: pajëgumų problemos ir politinès problemos.

Akivaizdžiausios, ko gero, yra pajëgumų problemos, kurių pagrindinè - tai, kad NRP ir EGRP remsis tais pačiais pajegumais (ang. double hatting). Ir nors tiek NATO, tiek ES pareigūnai tvirtina, kad EGRP ir NRP yra skirtos vykdyti skirtingas

\footnotetext{
${ }^{44}$ Missiroli A., „Flexibility and Enhanced Cooperation in European Security Matters“, Occasional Paper N. 6, January 1999, European Union Institute for Security Studies, Paris, 40.

${ }^{45}$ „Robertson: EU is „flabby giant“ not „pygmy“, 08 October 2002, http://www.euobserver.com/ index.phtml? aid $=7845$.

${ }^{46}$ „EU needs NATO’s new Response Force“, http://www.euobserver.com/index.phtml?aid=8090.
} 
misijas, ir todèl problemų dẻl pajẻgumų neturètų iškilti, verta pripažinti, kad vienu metu egzistuos apibrèžtas pajëgų ir visoms operacijoms reikalingų resursų kiekis. Kyla klausimas, ar praktiškai įmanomas toks scenarijus: europiečiu kariai su NRP uniformomis kovoja kare arba suduoda preventyvų smūgi, tada pasikeičia šiuos šalmus į EGRP uniformas ir toje pačioje vietoje vykdo taikos palaikymo misiją? Tuo pačiu metu vykstant kelioms, kad ir skirtingoms, operacijoms resursų klausimas neabejotinai iškils. Juk taikos palaikymo ar humanitarinei operacijai gali reikèti tu pačiu oro transporto pajėgumų, kaip ir intensyvesnei operacijai. Pajëgumai ir resursai, naudojami EGRP, tuo pačiu metu nebus prieinami NRP, ir atvirkščiai. Kadangi EGRP ir NRP veiklos sritys yra nepakankamai apibrèžtos ir ateityje gali plèstis, konkurencija dèl resursų gali ne tik tapti rimta kliūtimi EGRP ir NRP veiklos efektyvumui, bet taip pat kelti grèsmę tarptautiniam saugumui.

Neaišku, ar europiečiai, ir taip susiduriantys su didelėmis karinio sektoriaus finansavimo problemomis, sugebės užtikrinti pajėgumus NRP. Nors teigiama, kad NRP remsis „specialiais pajègumais“ ir nereikalaus papildomu išlaidų iš europiečių, visos EGRP kūrimo pajëgumų problemos gali persikelti i NRP. Be to, europiečiams reikès performuluoti savo išlaidų paskirstymą akcentuojant svarbiausias sritis (ko nereikejjo EGRP) ir tam, ko gero, taip pat reikés papildomų išlaidų. Jei Europos valstybėms nepavyks užtikrinti pakankamo karinių pajėgumų kiekio ir atitinkamo finansavimo, abu projektai gali būti pasmerkti nesèkmei. Būtina įvertinti ir karinių išlaidų pasiskirstymo problemas, sąlygotas atskirų valstybių nevienodų interesų. Mažai tikètina, kad šalių suinteresuotumas ir kaštai sutaps.

NATO ir ES Deklaracijoje dèl ESGP buvo numatyta, kad NATO ir ES dalinsis moderniomis technologijomis bei kitais daug kainuojančiais kariniais ištekliais. Viena vertus, tai išsprendžia nereikalingo NATO ir ES pajëgumų dubliavimo problemą. Kita vertus, realus šios nuostatos igyvendinimas yra kvestionuotinas. Pirma, pažangios technologijos valdymas reikalauja atitinkamo pasirengimo, todèl arba, skolinantis šiuos pajëgumus, reikès „skolintis“ ir personalą, arba kiekvienu atveju reikès organizuoti specialius mokymus. Gali atsitikti ir taip, kad kuris nors vienos ar kitos organizacijos narys nesutiks „skolinti“ brangios įrangos arba karių ir vetuos toki sprendimą, sutrukdydamas karinių operacijų eigą. Dar problematiškesnès gali būti komunikacijos ir dalijimosi informacija tarp dviejų pajegu perspektyvos. Bosnijoje ir Kosove, net veikiant vienos organizacijos struktūrose, buvo labai sudètinga koordinuoti europiečių ir JAV bei pačių europiečių tarpusavio veiksmus. Galima tik spėlioti, kokių sunkumų kils europiečiams bei amerikiečiams veikiant dviejų organizacijų struktūrose. Apskritai tikètina, jog sąveikumo problema tarp amerikiečių ir europiečių karinių pajėgų, kuri yra aktuali NATO struktūrose, dar labiau išryškès, jei veiks dvi organizacijos.

Vis dèlto pajègumų problemos, nors akivaizdesnès yra išsprendžiamos per tam tikrą laiką (kaip ir EGRP atveju atskirai), jei šalys yra suinteresuotos jas spręsti. Sunkiau sprendžiamos yra politinès problemos.

EGRP ir NRP bendros veiklos perspektyvos neabejotinai priklausys nuo transatlantinio ryšio stiprumo. Šaltojo karo metais transatlantinio ryšio tvirtumas buvo pagrindinis Europos saugumo garantas: Europos saugumo interesai buvo priklausomi nuo dominuojančios galybės (JAV) saugumo orientacijos, o JAV dislokavo regio- 
ne karines pajėgas, užtikrindama Vakarų Europos saugumą. Šaltajam karui pasibaigus, vis labiau šąlantys partnerių santykiai ir vis gausejantys ginčai tarp partneriu verčia susimąstyti, ar nauja pasaulio tvarka bei jos pasekmės neišardys ilgalaikès partnerystès. Silpnèjant transatlantiniam ryšiui, gali sumažèti NATO svarba, todèl NRP projektas nebeteks prasmès. Užduotys, kurios buvo numatytos NRP, gali būti igyvendintos JAV. Toks scenarijus neabejotinai turètų neigiamų pasekmių ir EGRP, kurios yra priklausomos nuo NATO pajègumų, vystymuisi ir veiklai.

R. Kepmin yra įsitikinusi, kad ilgainiui NRP ir EGRP taps nesuderinamos ${ }^{47}$, nes yra kuriamos remiantis visiškai kita saugumo samprata, su kuria susijęs bendradarbiavimo galimybių vertinimas, tarptautinès teisès interpretavimas, grèsmių apibrèžimas bei kovos priemonių pasirinkimas. Amerikietiškosios ir europietiškosios saugumo sampratų pagrindinius bruožus savo straipsnyje „Galia ir silpnumas“ (ang. Power and Weakness) išsamiai nagrinëja Robert Kagan ${ }^{48}$. Iš tiesų NRP remiasi JAV saugumo logika ir pateikia Europos šalims tris pagrindinius klausimus, ị kuriuos atsakius paaiškès realios NRP perspektyvos. Pirma, ar jos sutiks globaliai kovoti su asimetrinèmis grèsmèmis, kaip tarptautinis terorizmas ir masinio naikinimo ginklu plètra, ir, jei reikès, naudoti prevencinius veiksmus. Antra, ar jos yra pasirengusios savo saugumo politikos stilių keisti aktyvia veikla. Ar jos yra pasiryžusios užtikrinti resursus, reikalingus operacijoms, kurios išeina iš 5 str. remų?

EGRP remiasi europietiškaja saugumo vizija, kuri sietina su ES regioniniocivilinio veikejjo misija (žr. antrą straipsnio dalị) ir ilgalaike konfliktų prevencija. Konflikto atveju ES nori būti pajègi veikti greitai, tačiau naudojant ir civilinius pajègumus (policija, teisẻjais, civilinèmis institucijomis). Šiems civiliniams aspektams JAV beveik neteikè reikšmés savo strategijoje Irake. Turint omeny, kad NRP ir bus skirtos vykdyti operacijoms, panašioms i JAV vykdytą karinę kampaniją Irake, akivaizdu, kad europietiškoji ir amerikietiškoji kovos su grèsmèmis vizijos gali išsiskirti. Taigi atsižvelgiant ị filosofinius JAV ir europiečių užsienio politikos skirtumus svarbiausios problemos gali kilti dèl nesutarimo, kur ir kokias pajëgas naudoti.

Verta atkreipti dèmesị i tai, kad ESGP institucinè sąranga ir sprendimų prièmimo procesas yra per daug komplikuotas ir krizès atveju per lètas, todèl EGRP galès dalyvauti tik labai nedidelio intensyvumo operacijose. Veikiant NATO pirmumo principui, į Europos saugumo sampratą amerikiečiai gali būti linkę neatsižvelgti ir tai savo ruožtu sąlygotų įtampą tarp partnerių. Šia problemą galima būtų išspręsti, jei europietiška saugumo samprata, pagrịsta taikos palaikymu, būtų ijungta ị NATO struktūras, kur lengviau pasiekti kompromisus ir kur politinés ambicijos yra paremtos realia karine jèga. G. Hägglund mano, kad europinis ramstis NATO ir ESGP eventualiai bus sujungtas. Savo vizito Suomijoje metu jis tvirtino, kad jei Suomija netaps NATO nare, šio dešimtmečio pabaigoje tai nebeturès svarbos: ESGP ir europinis NATO ramstis bus tas pats ${ }^{49}$. Būtų logiška EGRP įtraukti ị NATO, tačiau ar taip atsitiks iš tiesų, priklausys tiek nuo pačių europiečiu ambicijų turèti bent iš dalies savarankiškas pajëgas ES struktūrose, tiek nuo JAV požiūrio ị Europos saugu-

\footnotetext{
${ }^{47}$ Kempin, (note 10).

${ }^{48}$ Kagan R., „Power and Weakness“, http://www.policyreview.org/JUN02/kagan_print.html.

${ }^{49}$ „Top military official predicts EU merge with NATO“, 17 January 2003, http://www.euobserver.com/ index.phtml? aid $=9048$.
} 
mo sampratą. Paaiškès ir tai, ar ji ir toliau bus vertinama kaip europiečių silpnumo išraiška, ar ị ją bus atsižvelgiama konstruojant saugumo strategiją. Vis dèlto jei europiečiai yra tikrai suinteresuoti bent daliniu EGRP savarankiškumu, EGRP turètų turèti atskirus pajègumus.

Diskusijos vyksta ir dèl NATO „pirmojo atsako“ teisès. NATO pirmumo principas leis krizių atveju išvengti nesutarimų dèl lyderystès, taip pat privers europiečius stiprinti karinius pajègumus. Tačiau transatlantiniams santykiams jis gali turèti ir neigiamų pasekmių. Problema ta, kad NRP ir EGRP bus paskirstyti ne tik kariniai darbai, bet, ko gero, ir misijos. Karinè kovos su terorizmu misija teks NRP, o civilinè, itraukianti ir šiokius tokius karinius instrumentus, - EGRP. Amerikiečiai baiminasi, kad toks padalijimas gali suformuoti dviaukštę struktūrą, kurioje europiečiai domésis tik nesunkiomis užduotimis (taikos palaikymu), o NATO, tiksliau amerikiečių modernioms karinėms pajëgoms, bus paliekamas visas ,juodas darbas“ - ten, kur „karščiau“50. Buvęs JAV ambasadorius NATO Robert E. Hunter savo publikacijoje „ESGP: NATO partneris ar konkurentas?“ (ang. ESDP: NATO's companion or competitor?) pateikiamose rekomendacijose sèkmingai ir efektyviai šiu organizacijų veiklai užtikrinti pabrèžia, kad ypač svarbu užtikrinti, jog būtų laikomasi NATO pirmumo principo ir vengiama tiek formalaus, tiek neformalaus darbo pasidalijimo tarp NATO ir ES ${ }^{51}$. Jo manymu, išlaidos gynybai ir pajègumai turi būti bendri. Abi organizacijos turi bendradarbiauti kovojant su pagrindine grèsme - terorizmu ir susieti skirtingus saugumo politikos aspektus (karini, politini, diplomatini, žvalgybinị, finansinị ir teisinị $)^{52}$. Vis dèlto, atisižvelgiant į EGRP ir NRP saugumo sampratų skirtumus, sunkiai įsivaizduojamas šių rekomendacijų igyvendinimas.

Europiečiai savo ruožtu nerimauja, kad NRP JAV naudosis siekdama ,susikonstruoti“" reikiamus pajėgumus savo vykdomoms misijoms. Vis rečiau selektyviai įsitraukdama ị operacijas, JAV veiks vadovaudamasi savo interesais, europiečiams palikdama ilgalaikes, mažo intensyvumo, mažai politiškai reikšmingas, bet daug kainuojančias užduotis. Suteikiant NATO pirmumo teisę, taip pat sumažinamas arba visiškai panaikinamas ES sprendimų prièmimo autonomiškumas tais klausimais, kurie iš tiesu yra svarbiausi - spręsti dèl jẻgos panaudojimo. Jei sprendimai bus priimami ŠAT, JAV turès veto teisę sprendžiant dẻl EGRP krizių valdymo ir EGRP tikrai taps tik „europietiškuoju ramsčiu“ NATO. Europiečių savarankiškumo ribojimas gali sąlygoti tai, kad jie bus linkę nusišalinti nuo daugumos misijų. Ar galima tikètis, kad valstybės rizikuos savo karių gyvybėmis, jei joms nebus suteiktas jokia sprendimų teisé?

Siekiant ịvertinti bendradarbiavimo tarp EGRP ir NRP perspektyvas, iškyla daugiau klausimų, nei galima pateikti atsakymų, tačiau verta atkreipti dèmesį i kai kurias reikšmingas tendencijas.

Ar NRP kūrimas ịpareigos europiečius didinti savo karinius pajègumus? Jei taip, tai laimètų ne tik NRP, bet ir EGRP, nes pajëgumai yra bendri. Priešingu atveju

\footnotetext{
${ }_{50}^{50}$ Amerikiečiams nerimą kelia Europos Sajungos siekiai kurti savarankišką gynybos organizaciją“ Laisvoji Europa, 20000313.

${ }^{51}$ Hunter R.E. „The European Security and Defence Policy: NATO's companion or competitor“, 2002, http://www.rand.org/natsec_area/products/MR1463.html.

${ }^{52}$ Ten pat.
} 
abu projektai būtų neveiksmingi. Kyla klausimas, ar nesužlugdys abiejų pajėgų sąveikumo problema. Ar šalys bus suinteresuotos ,skolinti“ viena kitai brangiai kainuojančią techniką bei savo karius misijose, kuriomis nebus suinteresuotos? Turint omeny, kad amerikiečių ir europiečių saugumo sampratos skiriasi, o europiečių interesai taip pat gali išsiskirti, šio pobūdžio problemos gali kelti rimtų problemų būsimai NRP ir EGRP veiklai.

NRP sèkmé priklausys ir nuo to, kiek europiečiai bus linkę keisti savo saugumo politikos sampratą. Jei jie laikysis nuomonès, kad NRP veikla turi būti organizuojama pagal europietiškosios saugumo politikos principus, NRP projektas nebus sèkmingas. Pirma, juo nebus suinteresuotos JAV, antra, NRP, kurios yra sukonstruotos pagal amerikietišką saugumo logiką, nebus pajëgios veikti.

Kiti svarbūs veiksniai, lemsiantys NRP ir EGRP perspektyvas, bus Europos identiteto ir transatlantinių santykių vystymosi tendencijos. Transatlantiniam ryšiui silpnėjant, gali sumažèti NATO svarba ir NRP nebeteks prasmès. Toks scenarijus sąlygotų ir EGRP, kurios remiasi NATO pajègumais, nesėkmę. Jei NATO atliks daugiau politinio forumo funkcijas, tiketina, kad JAV bus linkusios veikti savarankiškai, greičiausiai laikinų koalicijų struktūrose. Tačiau sprendimas gali iškelti JAV rimtu problemų dėl vienašališkumo, kurios tapo akivaizdžios Irake. Kita vertus, jei nepasiseks igyvendinti NRP projekto, tikètina, kad NATO svarba mažès, ir tai silpnins transatlantinị ryšį. Taigi NRP, NATO ir transatlantinio ryšio perspektyvos yra tarpusavyje susijusios. EGRP sèkmingos veiklos svarba šiame kontekste yra sąlyginai mažiausia. Net jei šis projektas nebus sėkmingai igyvendintas artimiausiu metu, šioms pajègoms numatytos misijos galès būti ịgyvendinamos NATO struktūrose. Vis dèlto kadangi EGRP ir NRP pajègumai yra tie patys, net jei EGRP nebus veiksmingos dèl, pavyzdžiui, institucinių problemų ES struktūrose, svarbu, kad europiečiai užtikrintų NRP, reikalingus pajëgumus.

Kol kas visi pritaria abiem projektams. Europiečiai yra suinteresuoti bet kokia kaina išlaikyti JAV NATO, o siekiant tai iggvendinti būtinos veikiančios NRP. Amerikiečiams NRP reikalingos, nes suteikia galimybę legitimizuoti savo saugumo sampratą ir su ja susijusius veiksmus. Be to, NRP labiau įtrauktų Europos sajungininkes ị regionus, kurie tradiciškai Europos šalių nelabai domina, ir nors šiek tiek palengvintų amerikiečių karinius kaštus. NRP leistų amerikiečiams išvengti problemų, su kuriomis jie susiduria Irake. Taigi tiketina, kad NRP projektas bus visiškai įgyvendintas iki numatytos datos (2006 m.). EGRP projektas amerikiečiams ir proatlantinių pažiūrų europiečiams priimtinas tik tiek, kiek skirtas stiprinti europiečių karinius pajègumus ir vykdyti labai riboto intensyvumo užduotis. Nepaisant kai kurių šalių, ypač Prancūzijos, polinkio EGRP skirti ambicingesnę rolę, panašu, kad artimiausiu metu (bent jau kol ES nepakeis savo identiteto ir regioninio veikejjo ị globalesnị) šios pajègos liks daugiau deklaratyvaus pobūdžio projektu ir dalyvaus tik mažose misijose, panašiose į tas, kurios jau yra vykdomos Makedonijoje ir Kongo Demokratinèje Respublikoje. Svarbu ir tai, kokie sprendimai dèl EGRP bus įtvirtinti ES Konstitucijoje, ar Europos politinè retorika bus paremta kariniais resursais. Gynybos išlaidos, ko gero, išliks vienu pagrindinių europiečių suinteresuotumo EGRP indikatoriumi. EGRP gali vaidinti svarbesnị vaidmenį tarptautinio saugumo struktūrose, tačiau tam būtini savarankiški pajëgumai, atskiros pajègos ir ES valstybiu 
vienybė. EGRP nebus pajëgios imtis svarbesnių misijų, jei ES nesugebės konsoliduoti labai išsiskiriančių valstybių interesų. Kita vertus, situacija gali pasikeisti, jei ES pavyks susidoroti su vidaus problemomis, jei plètra ir integracija vyks sėkmingai ir ES identitetas stiprès. Abiejų pajėgų vystymui gali įtakos turèti ir JAV administracijos pozicija bei visuomenès nuomonè tiek JAV, tiek ES šalyse. Svarbu ir tai, kuri organizacija sugebės pasiūlyti geresnes bendradarbiavimo su kitomis šalimis (Rusija, gal Kinija ir pan.) galimybes.

\section{Lietuvos dalyvavimo NRP ir EGRP perspektyvos}

Lietuva taps visateise ES ir NATO nare, todèl dalyvavimo EGRP ir NRP klausimas iškils ir Lietuvai. Nors NRP projektas dar naujas, Lietuvoje jau yra svarstoma, kuo lietuviai galètų prisidèti prie šių pajègų vykdomų operacijų. Buvo planuojama šioms pajègoms skirti vieną specialiujų pajègų eskadroną, kuris šiuo metu veikia operacijoje „Tvirta taika“ Afganistane.

Nors, kaip ir kitos Vidurio ir Rytų Europos (VRE) šalys, Lietuva pripažįsta NATO, kaip saugumo garanto, pirmenybę, Lietuva yra pasirengusi savo pajègomis prisidèti ir prie EGRP. 2001 m. neformalaus ES gynybos ministrų susitikimo metu buvo numatyta EGRP skirti po vieną mechanizuotą ir motorizuotą kuopos bei būrio dydžio pèstininkų vienetą, karo medikų skyrių, inžinierių būrị, specialiųjų pajègų būrị, vieną An-26 orlaivị, du Mi-8 sraigtasparnius, du išminavimo laivu, du karinius poligonus). Lietuva šiuo metu planuoja tiek NATO, tiek ES skirti tuos pačius pajëgumus.

Mažos šalys nedaug kuo gali prisidèti prie greito reagavimo pajëgų. Pirma, jos dažniausiai neturi brangiai kainuojančių pajėgumų, antra vertus, jų karinès pajègos yra kitokios struktūros, negu to reikia greito reagavimo pajègoms. Tai ypač aktualu Vidurio ir Rytų Europos (VRE) šalims, kuriose karinès pajègos buvo kuriamos remiantis teritorinés gynybos principu ir kurios susiduria su ekonominemis problemomis, nulemiančiomis nedideles gynybos išlaidas. Prahos viršūnių susitikimo metu G. Robertson pakvietė Europos šalis ieškoti galimybių prisidèti prie kuriamų NRP stiprinant „specialiuosius pajègumus“. Tarp šalių, kurios galètų skirti konkrečius pajėgumus, buvo minimos Čekija ir Rumunija ${ }^{53}$. Tai rodo, kad ir VRE šaliu pajègumai gali būti svarbūs NRP. Britų Kmdr Chris Parry pabrèžè, kad mažos šalys taip pat gali surasti savo vietą šiose pajègose. Jo manymu, „niekada néra per daug medicininių pajègumų“. Britas pripažino, kad tarp Europos ir JAV tebeegzistuoja milžiniškas atotrūkis karinių technologijų srityje, ir tvirtino, kad labai svarbu, jog šis atotrūkis bent jau nedidètų. Svarbiausia, jo nuomone, yra užtikrinti, kad šalyse veikiančios sistemos galètų būti inkorporuotos ị JAV sisteminị tinklą̧ ${ }^{54}$. VRE valstybės galètų NRP skirti karinès policijos, sprogmenų specialistų ir vairuotojų junginius. Kita vertus, nors šios šalys nedaug kuo gali prisidèti prie NRP, tikètina, kad jų narystė Aljanse pozityviai lems NATO vidinę dinamiką ir funkcionavimą. Jų pasitikejimas ir parama stipriai transatlantinei partnerystei reiškia, kad šios šalys bus aktyvios

\footnotetext{
${ }^{53}$ Powell, Rosenberg (note 11).

${ }^{54}$ (note 15).
} 
siekdamos išlaikyti šią partnerystę ir stiprins Aljansą. Todėl netgi neskirdamos NRP daug pajėgumų, savo politine parama Aljansui ir transatlantinei partnerystei šios šalys galètų padèti užtikrinti geresnes efektyvių NRP kūrimo sąlygas.

Nors Lietuva remia ESGP vystymą, tačiau pabrežia, kad ji neturètų konkuruoti su NATO, ir pripažįsta NATO svarbą bei pirmumą. Baiminamasi tradiciniu grèsmių, todèl NATO yra priimtinesnè kaip vienintelè organizacija, galinti pasiūlyti tinkamas ir efektyvias priemones kovai su šiomis grésmėmis. İ Rusiją dar dažnai VRE šalių (ypač Baltijos valstybių) žvelgiama kaip ị potencialią grèsmę bet kokia forma ir ilgesnejje perspektyvoje. Ilgametis Maskvos prieštaravimas narystei NATO lietuvių akyse įsivaizduojamas kaip Rusijos ambicijų patvirtinimas. Rusijos ekonominès ambicijos, neaiškūs ryšiai tarp verslo ir politinių sluoksnių ir bandymas manevruoti ,žaidžiant“ su Vakarų valstybių vadovais vis dar kelia nerimą. Nauji susitarimai tarp Rusijos ir NATO taip pat verčia nuogąstauti. Ar NATO elgsis taip, kaip iš jos buvo tikimasi i ją stojant? Ar NRP nereiškia, kad NATO imasi kitokios misijos? Ar 5 str. bus panaudotas Rusijos agresijos atveju? Nors NATO vadovai visada akcentuoja, kad kolektyvinė gynyba išlieka pagrindine Aljanso misija, tradicinè filosofija ir susirūpinimas savo suverenumu gali sulètinti šių šalių karines reformas pereinant prie specialių pajègumų.

Verta atkreipti dėmesį, kad VRE regionas, kurio dalimi yra ir Lietuva, - tai naujų ir klasikinių tradicinių grèsmių mišinys. Nelegali migracija, prekyba narkotikais, juodosios rinkos problemos šiai Europos daliai tiek pat reikšmingos, kaip ir karinių pajėgumų koncentracija ir kitos Šaltojo karo laikų problemos. Šiame regione egzistuoja ir unikalių regionui būdingų grèsmių: užšaldyti konfliktai (Moldova, Pietụ Kaukazas), unikalios geopolitinės situacijos (Kaliningradas) ir seno tipo autoritariniai režimai (Baltarusija) ir Rusijos organizuotas nusikalstamumas. Todèl regionui ne mažiau svarbūs ir „minkštojo“ saugumo instrumentai, kuriuos gali pasiūlyti EGRP.

Vis dèlto Lietuvos saugumo dienotvarkejje svarbiausia organizacija išlieka NATO. Nors egzistuojant rimtiems nesutarimams tarp amerikiečių ir europiečiu ar ivvykus NATO ir ES transformacijai dvigubas identitetas gali supainioti Lietuvos užsienio ir saugumo politikos prioritetus, tiketina, kad bent artimiausiu metu pirmenybė, kaip ir anksčiau, bus skiriama NATO. O prioritetine gynybos planavimo sritimi, ko gero, bus „specialūs pajëgumai“, kuriuos galima būtų naudoti ir NRP, ir EGRP vykdomose operacijose.

\section{Išvados}

Dar neveikiančių (ar tik iš dalies veikiančių) naujo pobūdžio struktūrų galimybių analizè - sudètingas procesas, reikalaujantis atsižvelgti ị daugybę įvairiomis kryptimis veikiančiu ir ne visada tiesiogiai susijusių su tiriamais objektais veiksnių. Siekiant išsiaiškinti NRP ir EGRP galimybes, apibrèžti šių pajègų rolę naujoje saugumo „architektūroje“ ir numatyti, koks bus jų tarpusavio ryšys bei įtaka tarptautiniam saugumui, straipsnyje pateikta NRP ir EGRP bei jų veikos perspektyvų analizé iškẻlè daug klausimų dẻl šiu pajėgų naudojimo, efektyvumo, sąveikumo bei galimos įtakos tarptautiniam saugumui. Nors šiandien dar sudètinga atsakyti į daugumą iš šiu klausimų, vis dèlto, galima įžvelgti kai kurias tendencijas, bylojančias apie vienokią 
ar kitokią greito reagavimo pajëgų vystymosi kryptị, taip pat išskirti veiksnius, neabejotinai lemsiančius tolimesnę jų evoliuciją.

EGRP vystymąsi neabejotinai lems tai, ar Europos šalims pavyks skirti pakankamai pajėgumų šių misijų igyvendinimui ir ar šie pajègumai bus efektyviai naudojami bei finansuojami. Karinių pajẻgumų trūkumą galima ištaisyti per tam tikrą laiką, jei šalių pastangos bus paremtos politine valia. Sudètingiau ES narèms gali būti išspręsti išsiskiriančių nacionalinių interesų keliamas problemas. Dẻl išsiskiriančių narių interesų ir nevienodo tarptautinio aktyvumo, ko gero būtų sudètinga net pateikti vienareikšmišką ES gintinų interesų sąrašą. Šie nesutarimai sąlygoja, kad ES šalys nevienodai supranta, kur pajègos turi būti naudojamos, kada jos turi būti naudojamos ir, pagaliau, kokių pajëgumų joms reikia. Europiečiai tarpusavyje nesusitaria ir dėl šiu pajègu statuso. Nesuderinamumo problemas komplikuoja tai, kad ES antrajame ramstyje nèra tvirto institucinio pagrindo, suteikiančio prielaidas skirtingų šalių interesų derinimui ir ịpareigojančio laikytis prisiimtų ịsipareigojimų. EGRP plètotė artimiausiu metu gali sulètèti ir dèl ES gilèjančio integracijos ir plètros.

Kol ES neišspręs vidaus problemų bei neužtikrins stabilumo bent jau prie ES sienų, ES šalims, ko gero, nepavyks užsitikrinti pakankamos paramos ir vienybès EGRP kūrimui. Kita vertus, iškilus grèsmei gyvybiškai svarbiems Europos šaliu interesams situacija gali pasikeisti. Vis dèlto artimiausiu laikotarpiu tikètina, kad, jei EGRP dalyvaus karinėse operacijose, tai bus labai riboto pobūdžio operacijos, panašios ị tas, kurios jau yra vykdomos Makedonijoje ir Kongo Demokratineje respublikoje. Tolimesnejje perspektyvoje sèkminga plètra ir integracija gali sąlygoti globalesnes ambicijas, tačiau, ir pradejjus veikti globaliai, lieka neaišku, ar ES nuspręs globalią veiklą remti kariniais ar civiliniais instrumentais. Vis dèlto EGRP projekto sèkmé ar nesékmè, nors ir svarbi Europos Sajungai, jei ši sieks globalesnio vaidmens, nèra tokia svarbi tarptautiniam saugumui. Šioms pajègoms numatytos misijos gali būti ịgyvendinamos ir NATO struktūrose.

Kadangi EGRP ir NRP pajėgumai yra tie patys, svarbu, kad europiečiai užtikrintų šiuos pajègumus. Priešingu atveju, tai gali sąlygoti NATO marginalizaciją, JAV „pasitraukimą“ iš Europos ir neigiamai veikti tarptautinị saugumą. NRP perspektyvas temdo ir tai, kad šios pajègos yra kuriamos vadovaujantis amerikietiška saugumo samprata. Neaišku, ar europiečiai bus linkę skirti savo pajėgumų JAV saugumo sampratos igyvendinimui. Bendradarbiavimo galimybes gali sumažinti ir JAV, jei NRP vertins kaip galimybę sukonstruoti pajęgas savo interesams ginti. Skirtingos saugumo sampratos gali ịstumti europiečius ir amerikiečius ị ilgus ginčus del šių pajėgų misijos ir naudojimo. NRP raidos perspektyvos yra svarbesnès nei EGRP, nes jos gali tiesiogiai veikti NATO raison d'etre ir taip veikti transatlantinị ryšį. Abiejų pajègų vystymui gali ịtakos turèti ir JAV administracijos pozicija bei visuomenès nuomoné tiek JAV, tiek ES. Svarbu ir tai, kuri organizacija sugebės pasiūlyti geresnes bendradarbiavimo su kitomis šalimis (Rusija, o gal Kinija ir pan.) struktūras.

EGRP ir NRP bendros veikos perspektyvos išlieka miglotos. Nors buvo susitarta dèl NATO ,pirmojo atsako“ teisès, o europiečiams ,paliktos“ tik labai ribotos užduotys, realus funkcijų pasidalijimas mažai tikètinas dèl politinès ịtakos problemų, dèl pajẻgumų nesuderinamumo ir trūkumo ir, pagaliau, dèl skirtingų saugumo sampratų, kuriomis remiantis konstruojamos vienos ir kitos pajègos. 
Nors kintanti tarptautinė aplinka verčia valstybes nuolat peržvelgti savo interesus ir koreguoti užsienio ir saugumo politikos pozicijas, tikètina, kad bent artimiausiu metu VRE šalys, o tarpe jų ir Lietuva, pirmenybę kaip ir anksčiau skirs NATO. Prioritetine gynybos planavimo sritimi, ko gero, bus „specialūs pajëgumai“, kuriuos galima būtų naudoti tiek NRP vykdomose operacijose, tiek JAV vadovaujamose laikinose koalicijose, tiek pagaliau ir kai kuriose EGRP misijose. 